\title{
Eset - wielofunkcyjna roślina Etiopii i terminologia z nią związana
}

\section{Eset - multifunctional plant of Ethiopia and terminology connected with it}

\author{
Seifu Gebru \\ Institute of Linguistic, Adam Mickiewicz University \\ ul. Międzychodzka 5 60-371 Poznań Poland \\ gebruseifu@poczta.onet.pl
}

\begin{abstract}
The aim of this article is to present the Ethiopian plant - Eset. Due to its many functions there is a vast terminology related to its cultivation, processing and application in everyday life. The first part, after the introduction explains how Eset is farmed and what are the names of parts of this plant and stages of its development. Next part shows how Eset serves as food in Ethiopia and what are the names of dishes based on Eset in Amharic language. Eset can also be used to produce some commodities - strings, mattresses, mats and bowls. All vocabulary collected in this research is a result of author's homeland education and personal communication with numerous informants who grow Eset. The important trait of Eset is an intergenerational tradition of its cultivation.
\end{abstract}

\section{Wstęp}

Pochodzę z plemienia Gurage z wioski Yagwağa znajdującej się w południowo-wschodniej części Etiopii. Dzieciństwo spędziłem biegając wśród eset. Moje plemię słynie z uprawy tej niezwykłej rośliny. Dzięki temu informacje do tego artykułu mogłem czerpać bezpośrednio ze swojego doświadczenia, a także od moich braci Shemsu i Nasyr'a oraz sąsiada Muhammada, którzy są rolnikami i w sposób profesjonalny zajmują się uprawą tej rośliny. Bezcennych informacji co do pracy kobiet na wsi, oraz procesu przygotowania eset do spożycia udzieliła mi moja bratowa Medina oraz siostra Amira.

Także inni mieszkańcy wioski chętnie dzielili się ze mną swoją wiedzą. Ludzie ci żyją nadal w tradycyjny sposób, uprawiają ziemię i hodują zwierzęta, tak jak ich przodkowie przed wiekami. Dzięki temu stanowią nieocenione źródło informacji o życiu, historii i tradycji plemienia Gurage.

Wszystkie zdjęcia do tego artykułu wykonałem osobiście w czasie mojego pobytu w Etiopii w 2004 roku. 


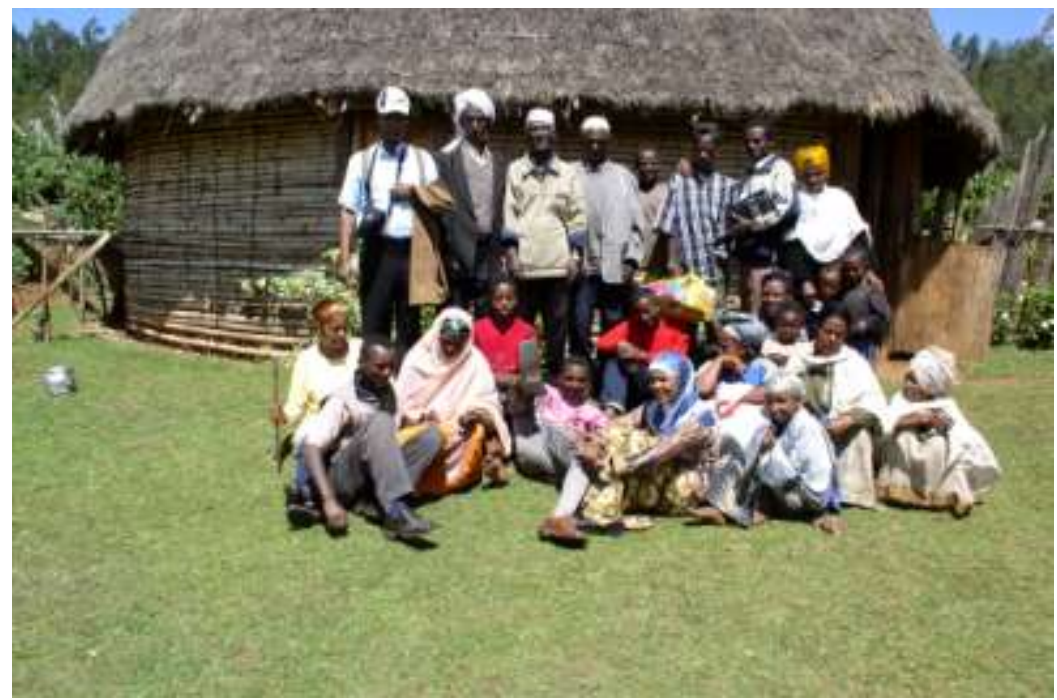

Zdjęcie 1. Autor z rodzina i mieszkańcami wioski Yagwaga.

\section{Charakterystyka eset}

Roślina ta występuje pod kilkoma nazwami. W języku guraginia określa się ją jako eset, w języku amharskim inset, w literaturze można spotkać określenie enset. Ze względu na swoje podobieństwo do bananowca dość powszechnie nazwana jest fałszywym bananem. Jest ona obok kawy i teffu ${ }^{1}$ najbardziej popularną rośliną uprawną Etiopii. Wytrawny rolnik jest w stanie wyróżnić ok. 200 rodzajów eset, w zależności od jego wysokości, grubości pnia, koloru liści, a także smaku korzenia.

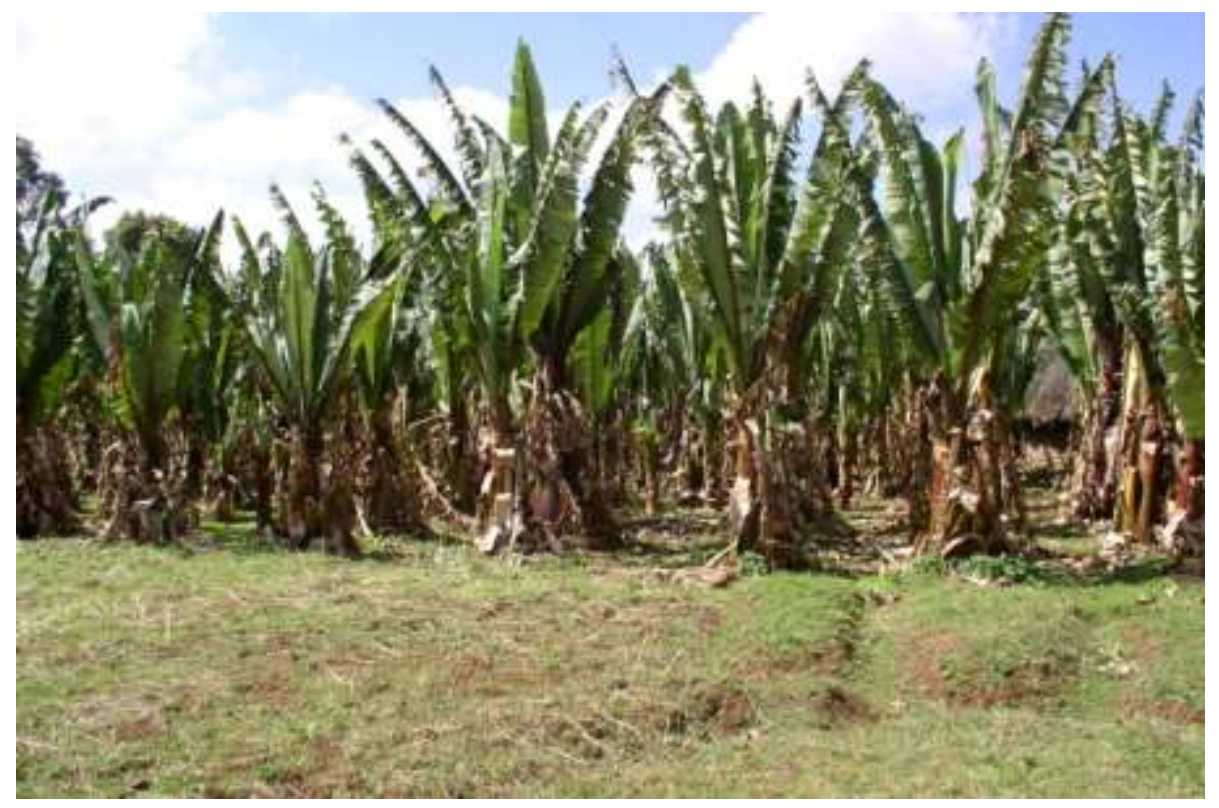

Zdjęcie 2. Uprawa eset.

Jest to roślina endemiczna, występująca jedynie w Etiopii i to głównie w jej południowowschodniej części oraz w rejonie Sidamo. Wymaga ona wieloletniego i bardzo skomplikowanego cyklu uprawy. Czas od momentu posadzenia, aż do uzyskania dojrzałej rośliny wynosi od 12 do 15 lat i zależy od jakości gleby i klimatu, a także od staranności uprawy. Plony są najlepsze na

\footnotetext{
${ }^{1}$ Teff - inna nazwa miłek abisyński rodzaj zboża występujący wyłącznie na terenie Etiopii. Robi się z niego indżerę, rodzaj dużego naleśnika. Jest to podstawowa potrawa Etiopczyków.
} 
glebach, na których przez lata bez przerwy rósł eset. Pola oraz sposób uprawy przekazywane są z pokolenia na pokolenie. Gdy ojciec zmuszony jest przekazać synowi ziemię, na której dotąd nie rósł eset, bo np. nie jest jego pierworodnym synem, to pomimo ciężkiej pracy nie uzyska on wystarczających plonów, aby utrzymać swoją rodzinę. Jest w zwyczaju, że ojciec przeznacza część swoich zbiorów na wsparcie syna. Trwa to przez kilka lat, aż nowe pole zacznie rodzić w odpowiedni sposób.

Wydaje się, że przyczyną braku rozprzestrzeniania się eset na inne tereny jest jego trudny i długotrwały cykl uprawy. Tak naprawdę zajmuję się nim jedynie plemię Gurage. A szkoda, bo ze względu na swoje skromne wymagania dotyczące wody, potrafi przetrzymać nawet bardzo długie okresy suszy. Dzięki tej szczególnej zdolności rolnicy, którzy uprawiają tę roślinę nie tracą plonów i rzadko cierpią głód. Stanowi on także ważne źródło materiału, do wyrobu wszelkiego rodzaju drobnych sprzętów codziennego użytku oraz domów, płotów itp. Szacuje się, że dla ok. $10 \mathrm{mln}$ ludzi stanowi on podstawę codziennego utrzymania.

Po klęsce głodu w 1984 roku, wywołanej długotrwałą suszą, która nawiedziła północne rejony Etiopii, rząd w obawie przed rozszerzaniem się obszarów występowania niedoborów wody, zalecił uprawy eset tam, gdzie jest to tylko możliwe. Dlatego w ostatnich czasach obszar upraw eset nieco się rozszerzył i objął część plemienia Oromo, zamieszkującego w pobliżu Gurage oraz rejon Sidamo.

\subsection{Budowa eset}

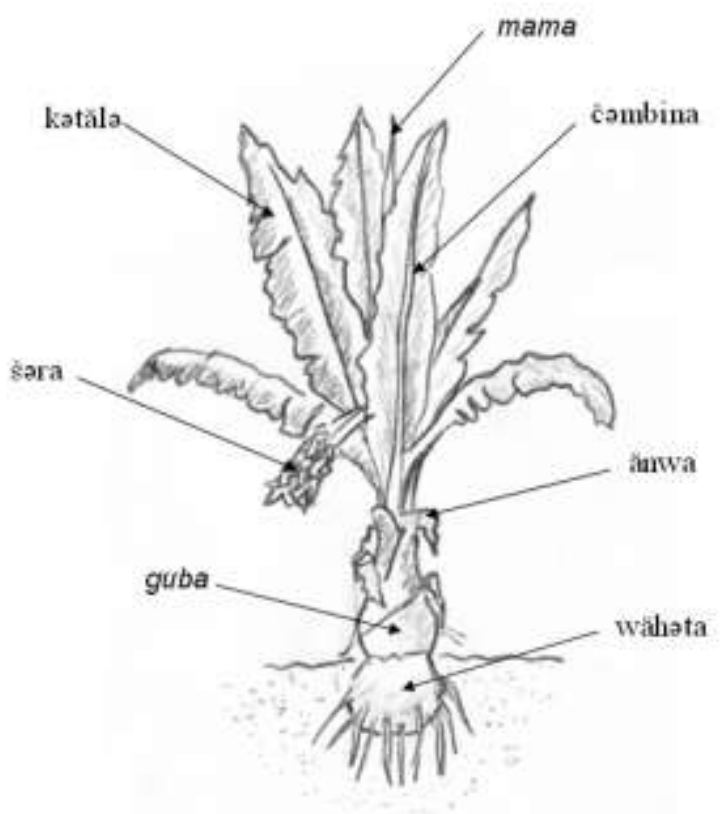

Rysunek 1. Budowa eset.
Eset składa się z następujących części:

> Wähəta - potężny korzeń.

$>$ Guba-gruby pień.

Katäla-ogromne liście.

> Čambina - grube łodygi przechodzące przez całe liście.

$>$ Šra - pojedynczy duży kwiat w środku, którego znajduje się kiść $\mathrm{z}$ krótkimi, zielonymi owocami, przypominającymi banany, występuje on jedynie u roślin w pełni dojrzałych.

$>$ Änwa-obumarłe, suche części guba.

$>$ Mama - nowy, dopiero rozwijający się środkowy liść.

> Inakorkəna - rdzeń pnia rośliny.

\subsection{Uprawa eset}

Uprawa eset wymaga szczególnej staranności i dbałości. Aby osiagnąć odpowiedni efekt końcowy należy zachować następujące zasady postępowania:

$>$ Wszystkie prace należy wykonywać w porze suchej, która trwa od października do maja.

$>$ Dostarczać odpowiednie ilości naturalnego nawozu i obkładać nim dokładnie każdą roślinę.

$>$ Co dwa lata należy spulchniać ziemię, tak aby była dostatecznie natleniona.

$>$ Stare łodygi i liście należy regularnie usuwać, żeby umożliwić łatwiejszy rozwój nowym.

$>$ Chronić rośliny przed zwierzętami zwłaszcza krowami i kozami, ponieważ zjadają tylko liście, pozostawiając gołe łodygi, co może spowodować obumieranie rośliny. 
$>\mathrm{W}$ czasie pory deszczowej ziemię między eset porasta trawa zwana muğa ${ }^{2}$, którą należy ścinać gdyż chłonie ona wodę potrzebną eset. Poza tym stanowi ona doskonałą karmę dla zwierząt, które podczas pory deszczowej zamknięte są w pomieszczeniach. Muğa wycinana jest ręcznie za pomocą narzędzia zwanego merded $^{3}$, ponieważ nie można wpuścić zwierząt między eset. Jest ona niezwykle ciężka, dlatego przenosi się ją za pomocą czegoś w rodzaju noszy zwanych matraša. Aby tego dokonać potrzebne są co najmniej dwie osoby.

$>$ Eset sadzi się zawsze w pobliżu domów, ponieważ:

$>$ Dym z palonego drewna na paleniskach domowych, przenika przez dachy kryte trawą lub słomą i wydostaje się na zewnątrz. Wpływa on korzystnie na rozwój eset.

$>\mathrm{W}$ domach zwanych sar bet $^{4}$ razem z ludźmi przebywają zwierzęta. Ich nawóz wykorzystuje się do użyźniania gleby wokół eset. Natomiast zwierzęta karmione są liśćmi tej rośliny. Ułatwia to w znaczny sposób pracę.

$>$ Jako roślina na codzień wykorzystywana w gospodarstwie domowym, powinna być łatwo dostępna.

$>$ Ułatwione jest pilnowanie zwierząt domowych, aby nie czyniły szkód w uprawach.

\subsection{Etapy uprawy eset}

Do uprawy eset potrzebne są aż cztery pola. Każde pole ma ściśle określone przeznaczenie i tylko na nim uprawia się rośliny będące w konkretnej fazie rozwoju. Wyróżniamy następujące etapy uprawy eset:

$>$ Fonfo - eset rozmnaża się za pomocą sadzonek. W celu ich uzyskania wybiera się $4-5$ letnią roślinę, wokół której za pomocą noża täbäčă obkrawa się ziemię, odcina korzenie boczne od głównego i ruchami wahadłowymi obluzowuje pozostałą część guba i wähəta. Całość wyciaga się z gleby, ścina za pomocą täbäčä ok. $20 \mathrm{~cm}$ powyżej korzenia, po czym wsadza ponownie w ziemię $\mathrm{w}$ dowolnym miejscu. Wszystko to wymaga od rolnika sporego wysiłku.

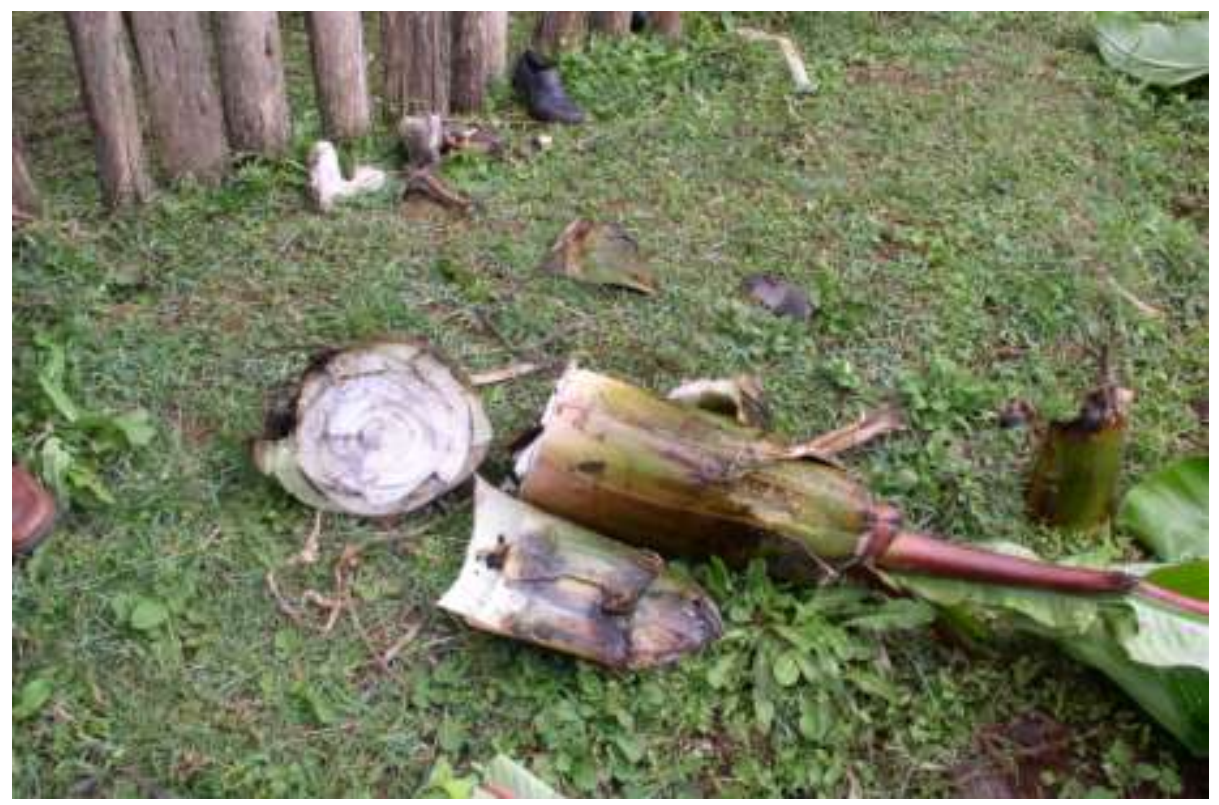

Zdjęcie 3. Wycięty eset na fonfo.

\footnotetext{
${ }^{2}$ Muğa - rodzaj trawy o długich, miękkich, bardzo mocno chłonących wodę źdźbłach.

${ }^{3}$ Merded - długi zakrzywiony nóż zębaty z cienkim, wydłużonym trzonkiem, służący do wycinania trawy

${ }_{5}^{4}$ Sar bet - w języku guraginia ,dom pokryty trawą”.

${ }^{5}$ Täbäčä - długi, gruby, szeroki, mocny nóż o wyprofilowanym drewnianym trzonku, służący do ścinania eset, a także obkrawania gleby wokół niego.
} 
Następnie starannie usuwa się rdzeń rośliny inəkorkəna, a powstały w ten sposób otwór zaślepia się ziemią lub kamieniem, a następnie wsadza w glebę całkowicie go obsypując.

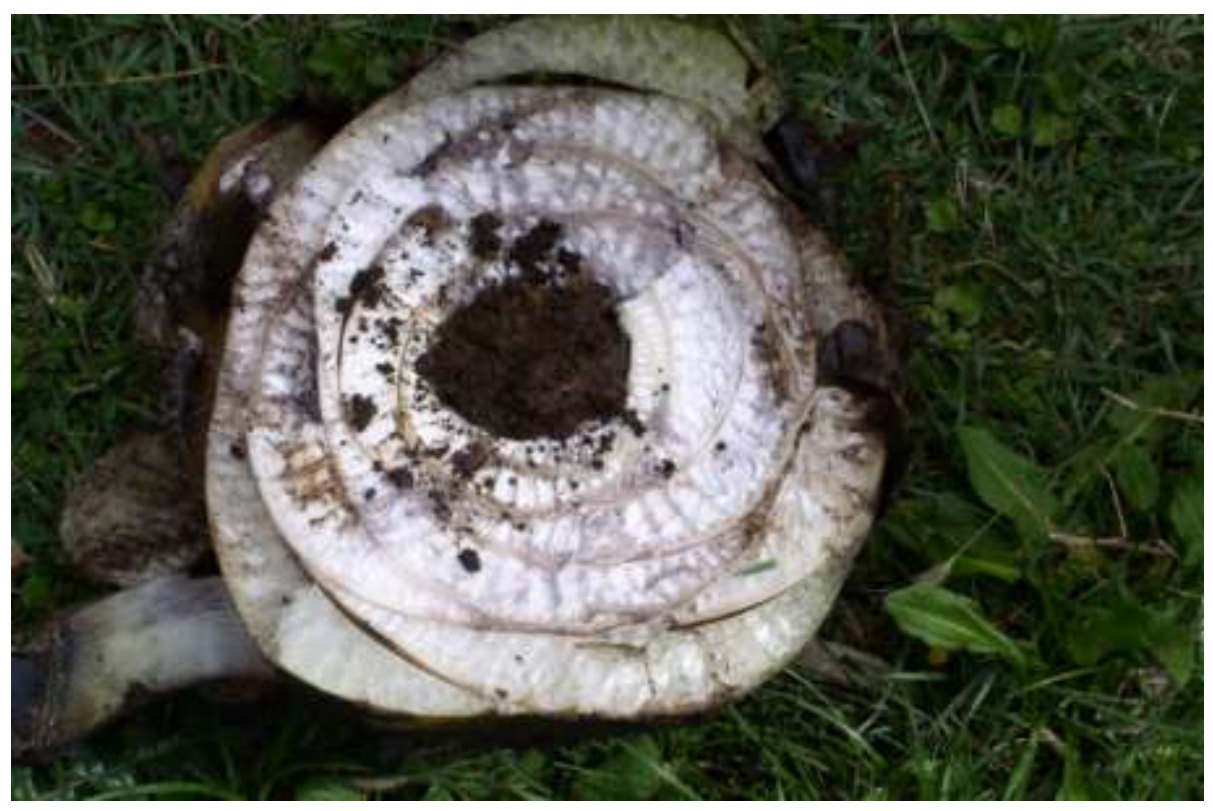

Zdjęcie 4 Eset z zaślepionq dziurq po usunięciu końcówki inəkorkana.

Zabieg ten powoduje, że roślina przestaje rozwijać się w sposób dotychczasowy, a zaczyna wypuszczać duże ilości młodych pędów tworząc kępę zwaną fonfo.

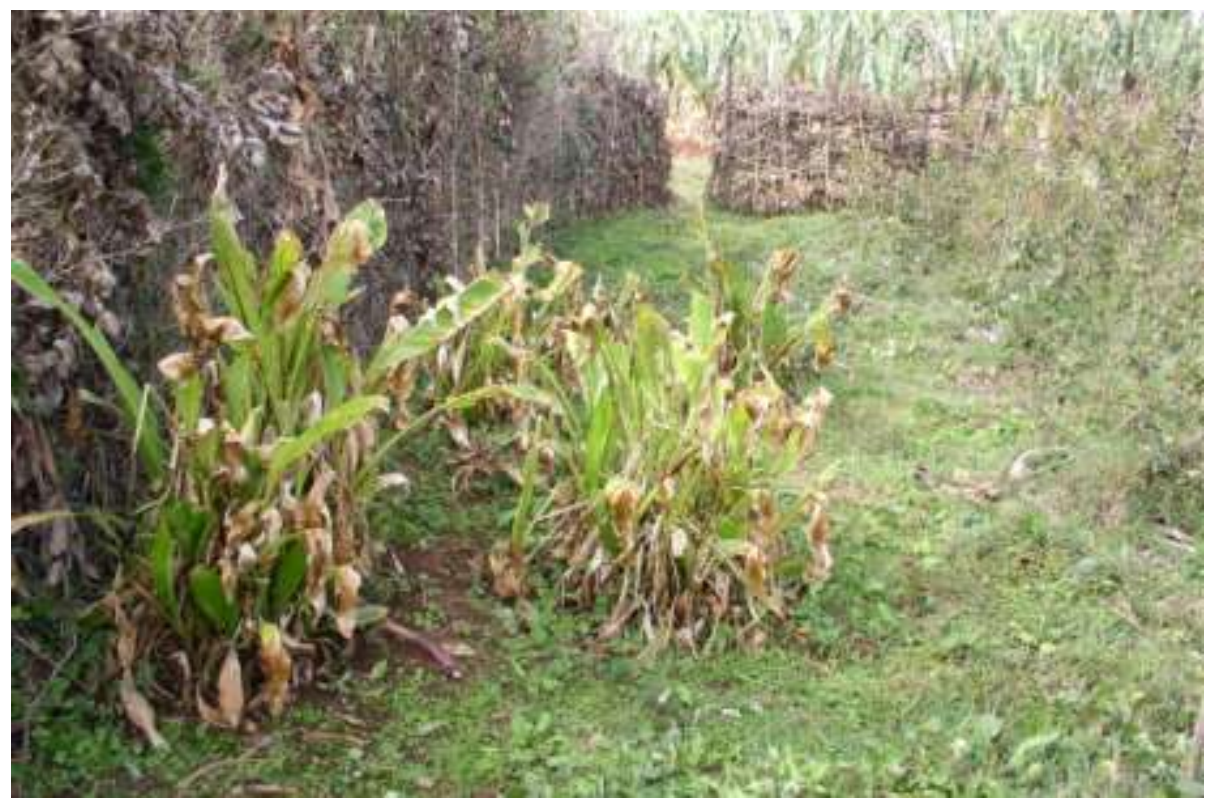

Zdjęcie 5. Kępa fonfo.

Rośnie ona przez ok. 2 lata. W tym czasie nie należy ścinać liści.

$>$ Səтua - na tym etapie fonfo w całości wyciąga się z ziemi i rozdziela na pojedyncze pędy. 


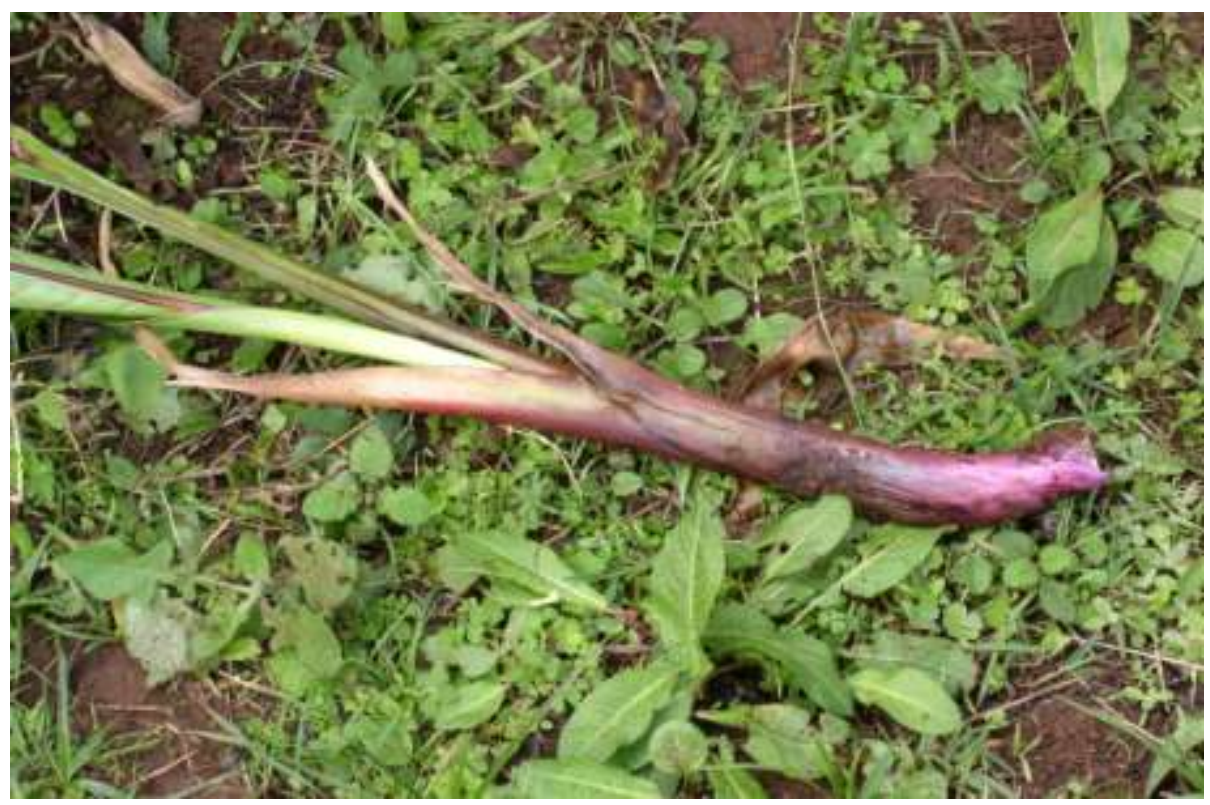

Zdjęcie 6. Pojedynczy pęd fonfo.

Do dalszej uprawy wybiera się tylko zdrowe sadzonki. Suche, zbyt małe lub uszkodzone przeznacza się na karmę dla krów.

Wcześniej przygotowuje się pole, na którym odpowiednio spulchnia się glebę za pomocą narzędzia zwanego maresza i użyźnia naturalnym nawozem.

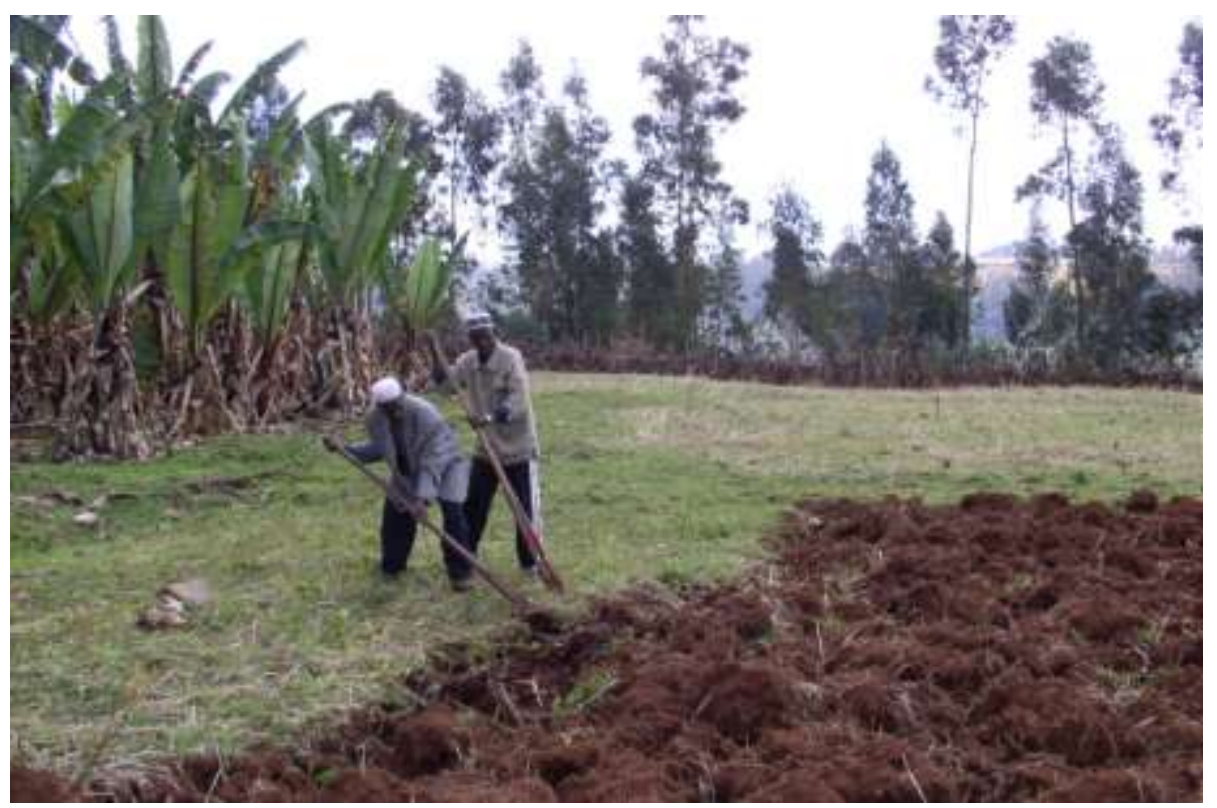

Zdjeccie 7. Przygotowanie pola pod eset.

Młode pędy sadzi się dość gęsto, po dwie rośliny obok siebie, długimi rzędami. Noszą one teraz nazwę səmua. W porze suchej wymagają częstego i całkowitego ścinania liści, aż do gołego pnia guba. Pozostają w tym miejscu przez kolejne dwa lata.

\footnotetext{
${ }^{6}$ Maresza - tradycyjne narzędzie służące do spulchniania ziemi. Rodzaj drewnianej motyki wykonanej z jednego kawałka drewna rozwidlającej się na dwa ostre końce obłożone dla wzmocnienia metalem. Przy rozwidleniu mocno związane sznurkiem.
} 


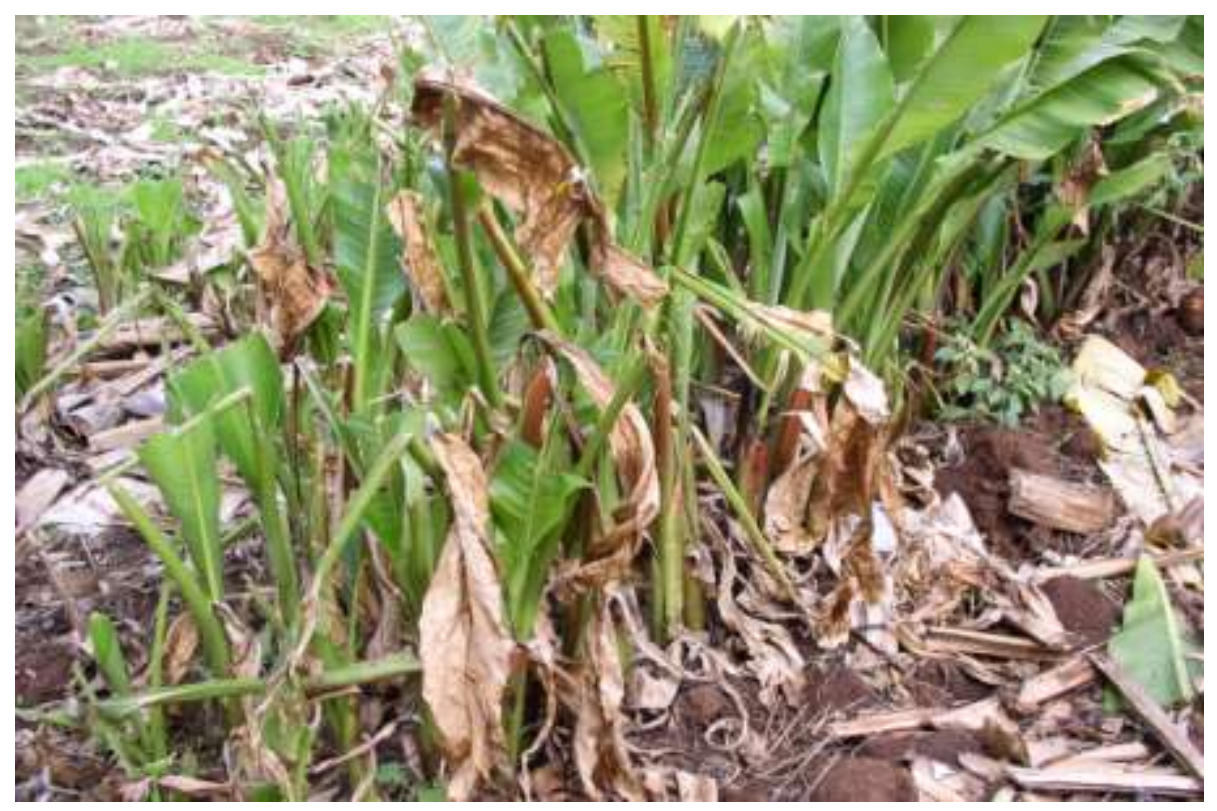

Zdjęcie 8.Eset w fazie Səтиа.

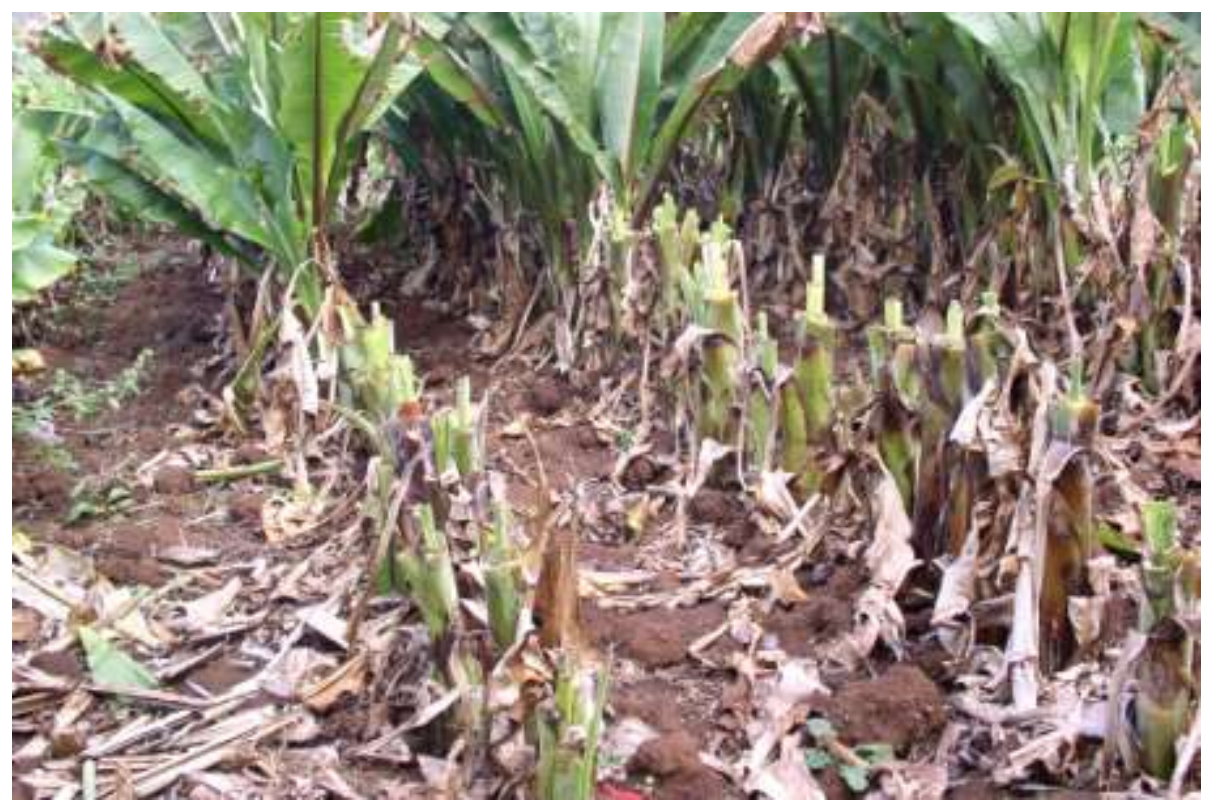

Zdjęcie 9. Obcięty eset $w$ fazie samua.

> Mäsərä - ponownie eset wyciaga się z ziemi, oczyszcza z liści i przenosi na kolejne pole. Wsadza długimi rzędami na kolejne dwa lata, robiąc jeszcze większe odległości 


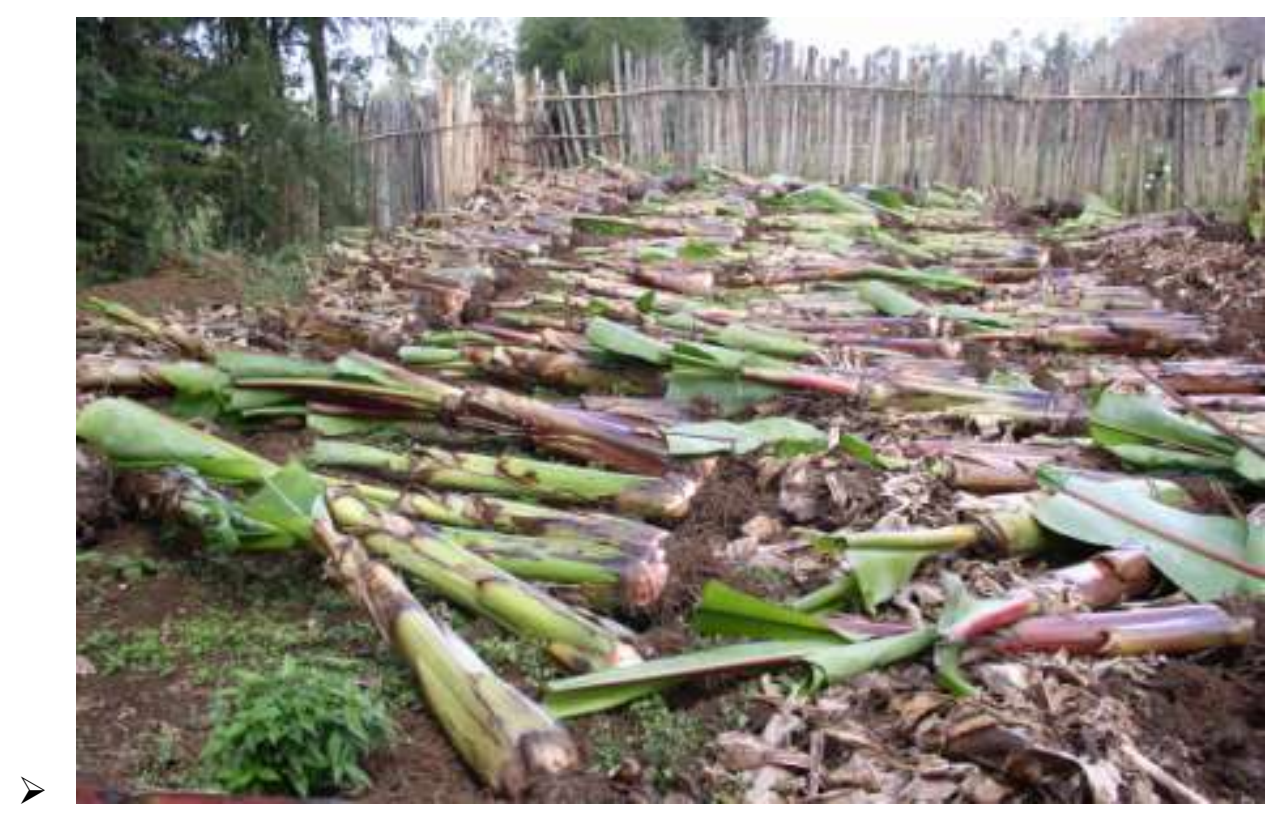

Zdjęcie 10. Mäsarä przygotowane do sadzenia.

między poszczególnymi roślinami. Znów często i starannie obcina się liście. W czasie pory deszczowej należy pamiętać o wycinaniu trawy muğa.

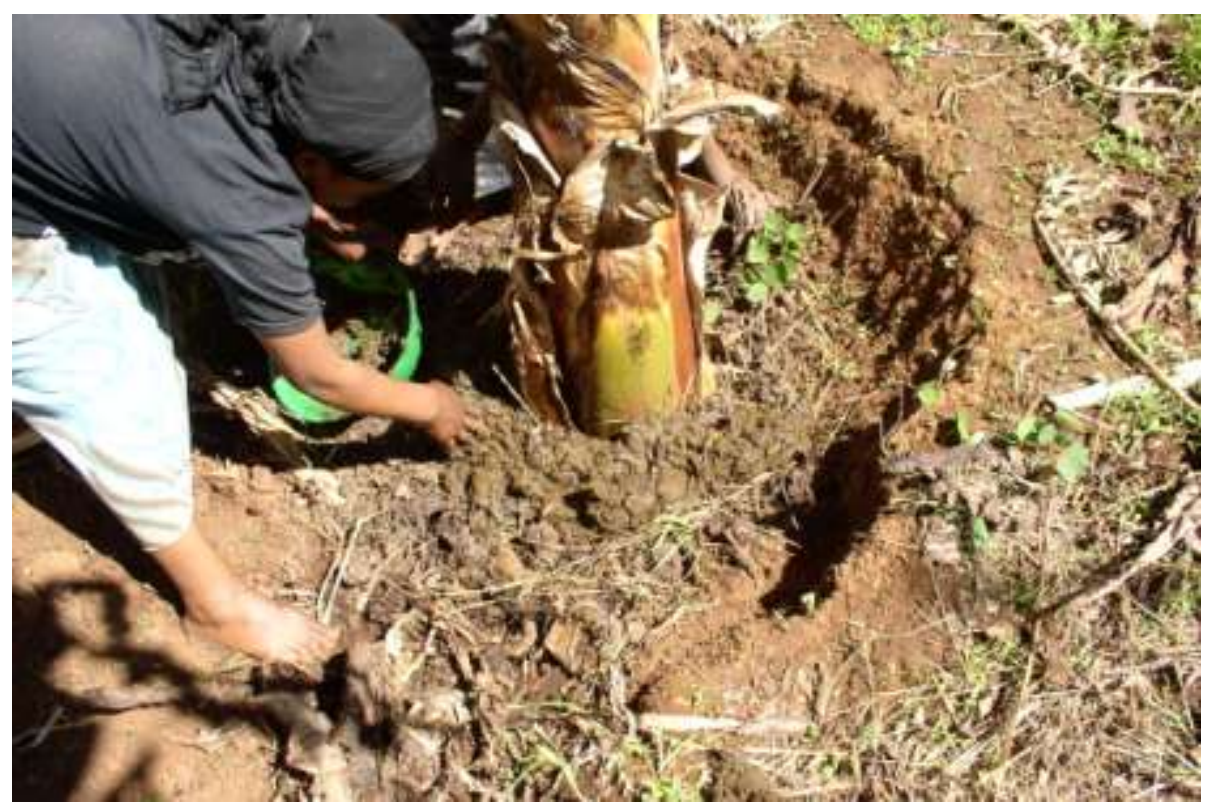

Zdjęcie 11. Użyźnianie naturalnym nawozem əbät.

Ich rozwój wymaga dużej ilości naturalnego nawozu, dlatego odkopuje się korzeń wähata i obkłada ręcznie odchodami zwierzęcymi - abät. Czynność tę wykonują wyłącznie kobiety.

> Haba - etap nie wiele różniący się od poprzedniego. Jedynie rośliny wsadza się zdecydowanie luźniej, aby mogły swobodnie rosnąć. Trwa dwa lata. 


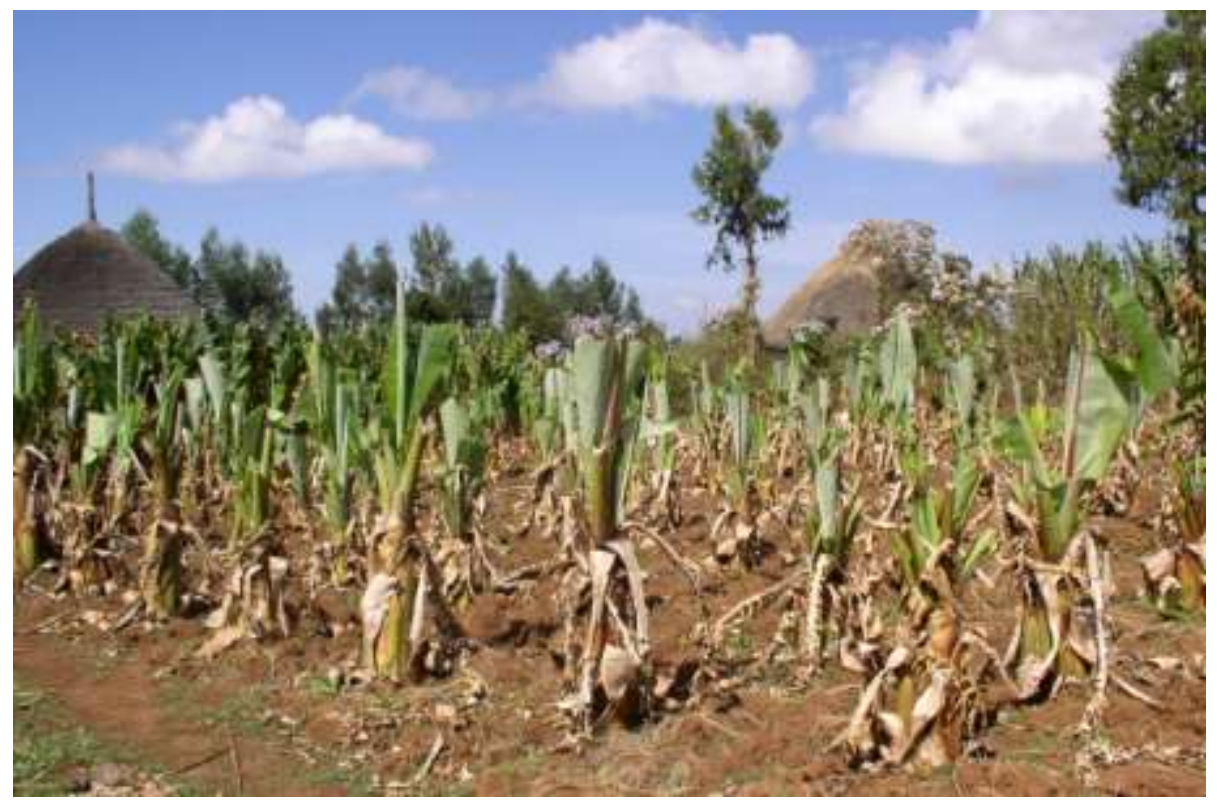

Zdjęcie 12. Eset w fazie həba.

> Po fazie həba następuje ostatni etap rozwoju eset, który nie ma konkretnej nazwy. Rośliny wsadzane są $\mathrm{w}$ odpowiednio przygotowane miejsca po wcześniej już wyciętych do spożycia. Raczej nie obcina się już liści, ewentualnie pojedyncze, boczne. Roślina nadal wymaga dokładnego obkładania nawozem. Eset jest w pełni dojrzały, gdy wypuści pojedynczy kwiat - šara.

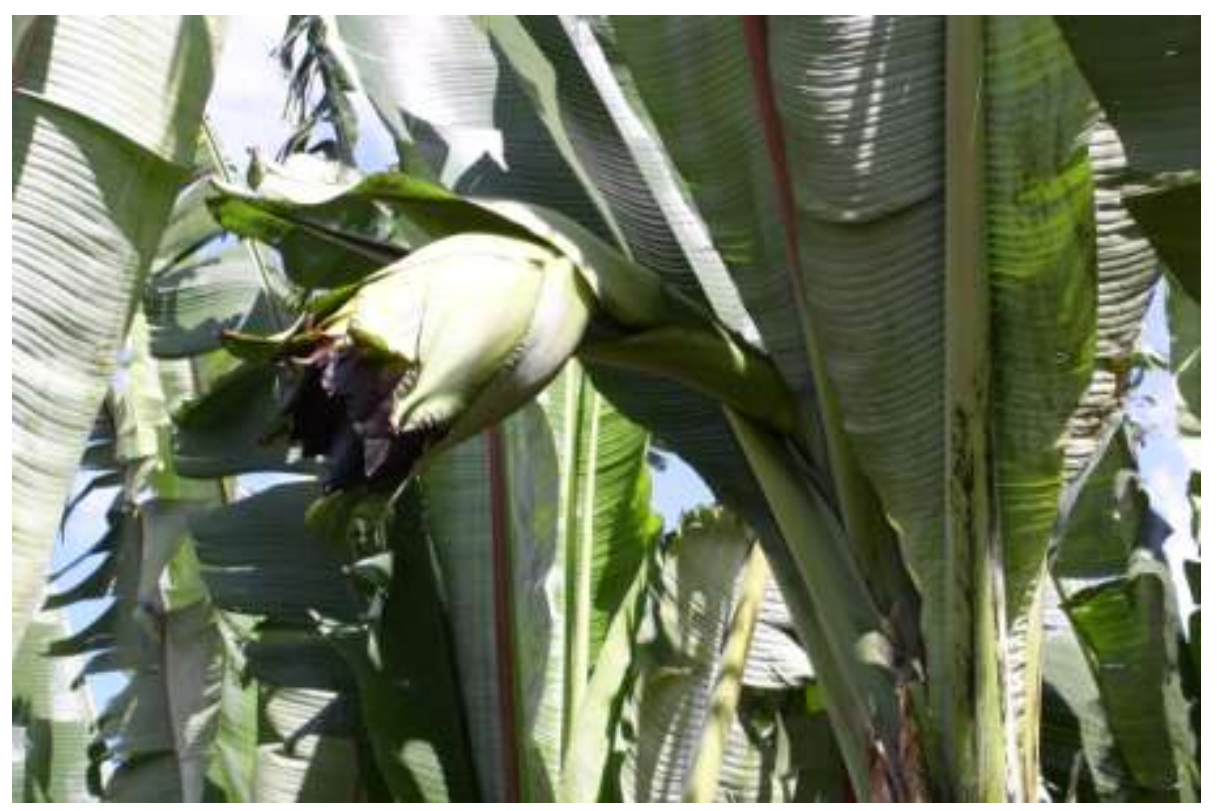

Zdjęcie 13. Šra.

Jest to sygnał, że z jego wycięciem nie należy zbyt długo zwlekać, gdyż roślina zaczyna obumierać i cały wieloletni wysiłek może pójść na marne. Najczęściej jednak rolnik ścina roślinę przed zakwitnięciem, jeśli uzna, że według niego jest wystarczająco dojrzała lub zmusza go do tego sytuacja życiowa. 


\section{Wykorzystanie eset jako produktu do spożycia}

\subsection{Wusa ( kočo)}

Wusa znane także pod amharską nazwą kočo, jest jedną z potraw, z której słynie plemię Gurage. Stanowi ono podstawę jego wyżywienia. Najlepsze wusa robi się z eset z rodzaju kancəwä, kəbəna i näcəwä. Bezcenną cechą tej potrawy jest to, że można ją wykonać nawet $\mathrm{z}$ nie w pełni dojrzałej rośliny. Jeśli np. rolnik jest biedny, ma problemy $\mathrm{z}$ wyżywieniem swojej rodziny, to może skorzystać z dobrodziejstw eset w każdej chwili. Jednak najlepszej jakości wusa powstaje, gdy roślina dojrzeje i wypuści kwiat šara. Ścina się wtedy liście zwane katäla, pozostawiając pień guba z korzeniem wähota, wyciąga się z ziemi i oczyszcza za pomocą noża täbäčä.

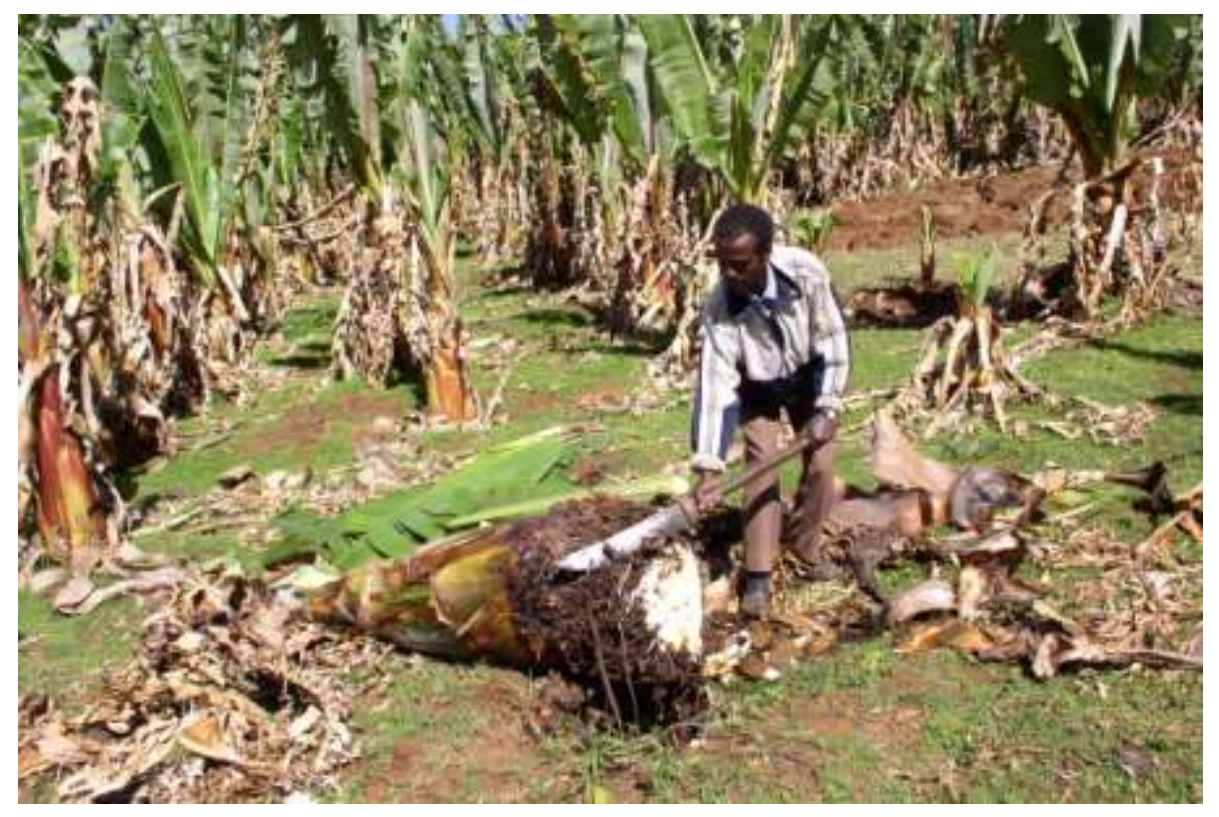

Zdjęcie 14. Wyciagnięty eset, w trakcie oczyszczania wähata nożem täbäčä.

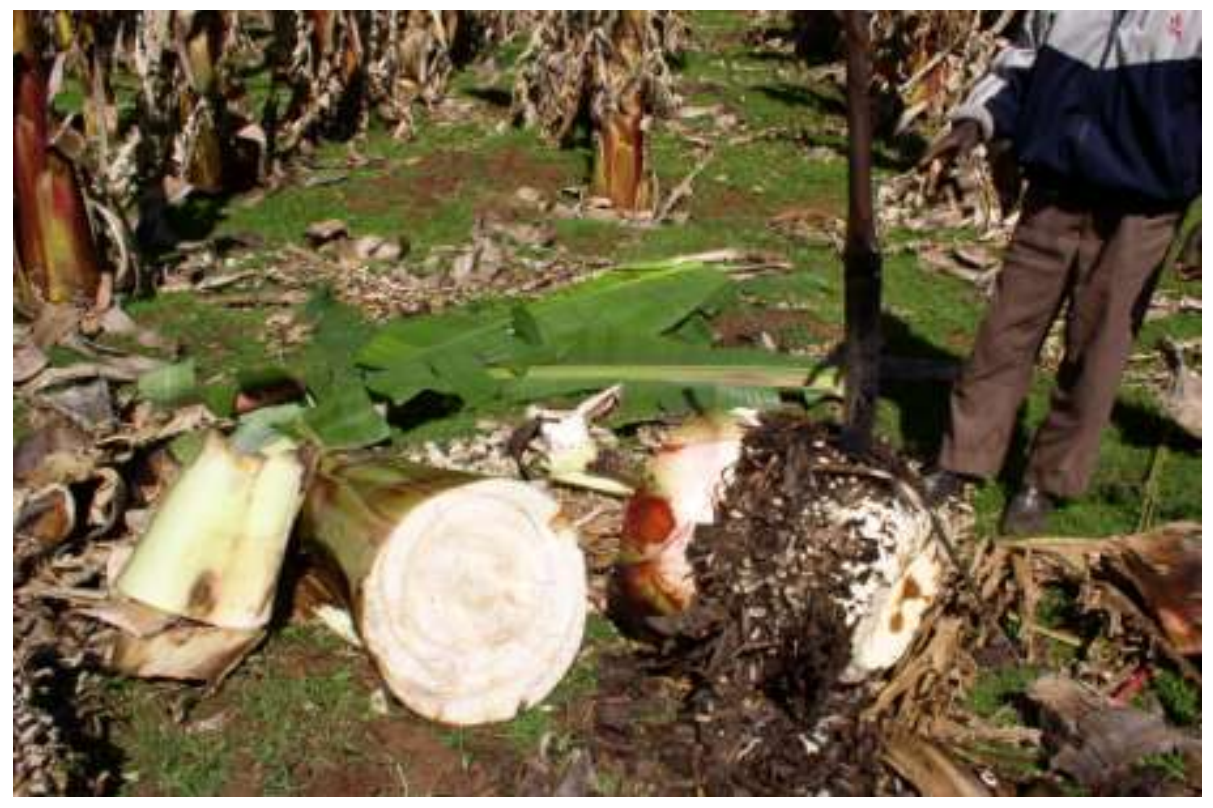

Zdjęcie 15. Odcięty wähata od guba. 
Pień obcina się na wysokości ok. $20 \mathrm{~cm}$ od korzenia. Wcześniej przygotowuje się liście katäla, które służą jako mata zabezpieczająca przed zanieczyszczeniem czystych części rozbieranej rośliny. Wähəta odwracana jest zapiaszczoną, brudną częścią do góry, tak aby łatwiej można było ją oczyścić. Za pomocą specjalnych noszy - matraša - dwie, trzy osoby transportują go na miejsce, gdzie zostanie poddany dalszej obróbce.

Guba (pień), wcześniej odcięty i pozbawiony liści, oczyszcza się z suchych części i rozwarstwia na płaty.

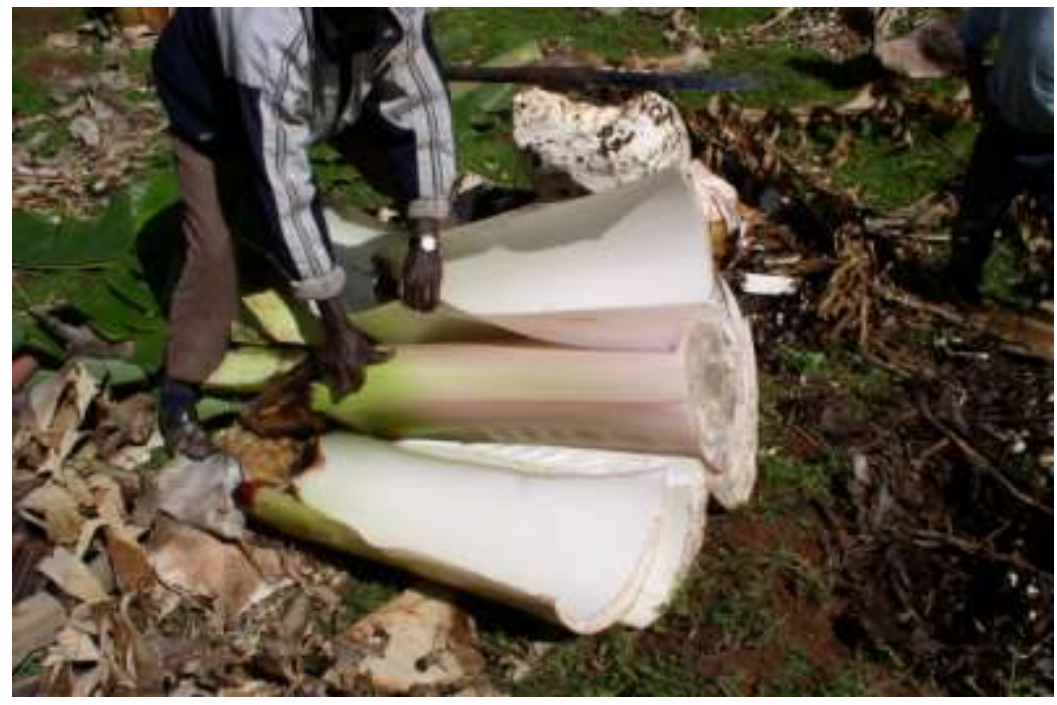

Zdjęcie 16. Rozwarstwianie guba.

Pozostaje jedynie inəkorkəna - rdzeń pnia stanowiący część niejadalną i przeznaczony na karmę dla zwierząt.

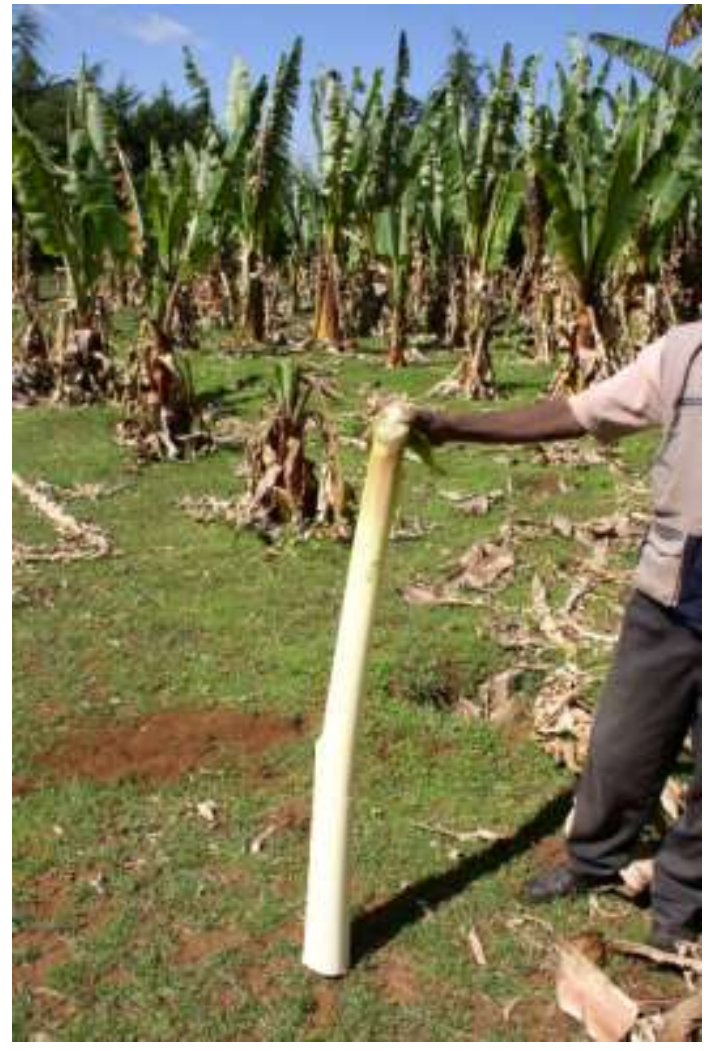

Zdjęcie 17. Inəkorkana - rdzeń pnia eset. 
Następnie płaty przenosi się tam gdzie znajduje się już wähota. Do tego momentu eset zajmowali się tylko mężczyźni (z wyjątkiem użyźniania gleby). Teraz kończy się ich rola. Dalszym przygotowaniem wusa zajmują się wyłącznie kobiety. Mężczyznom zakazuje się, pod groźbą zhańbienia, uczestniczenia $\mathrm{w}$ dalszych pracach. Nie wolno im nawet dotknąć niegotowego do spożycia wusa.

Dalsza obróbka eset jest na tyle pracochłonna i czasochłonna, że przekracza możliwości jednej kobiety. Zbierają się więc one po kolei w każdym z gospodarstw, aby pomóc sobie wzajemnie. Jeśli $\mathrm{z}$ jakiś powodów nie można skorzystać $\mathrm{z}$ sąsiedzkiej pomocy, trzeba wynająć wykwalifikowane pracownice.

Część kobiet na siedząco, za pomocą specjalnego narzędzia zwanego žəbanəgiba ${ }^{7}$ rozdrabnia wähəta na drobne wióry. Na podstawiony liść eset spływa mętny płyn zwany atamät’.

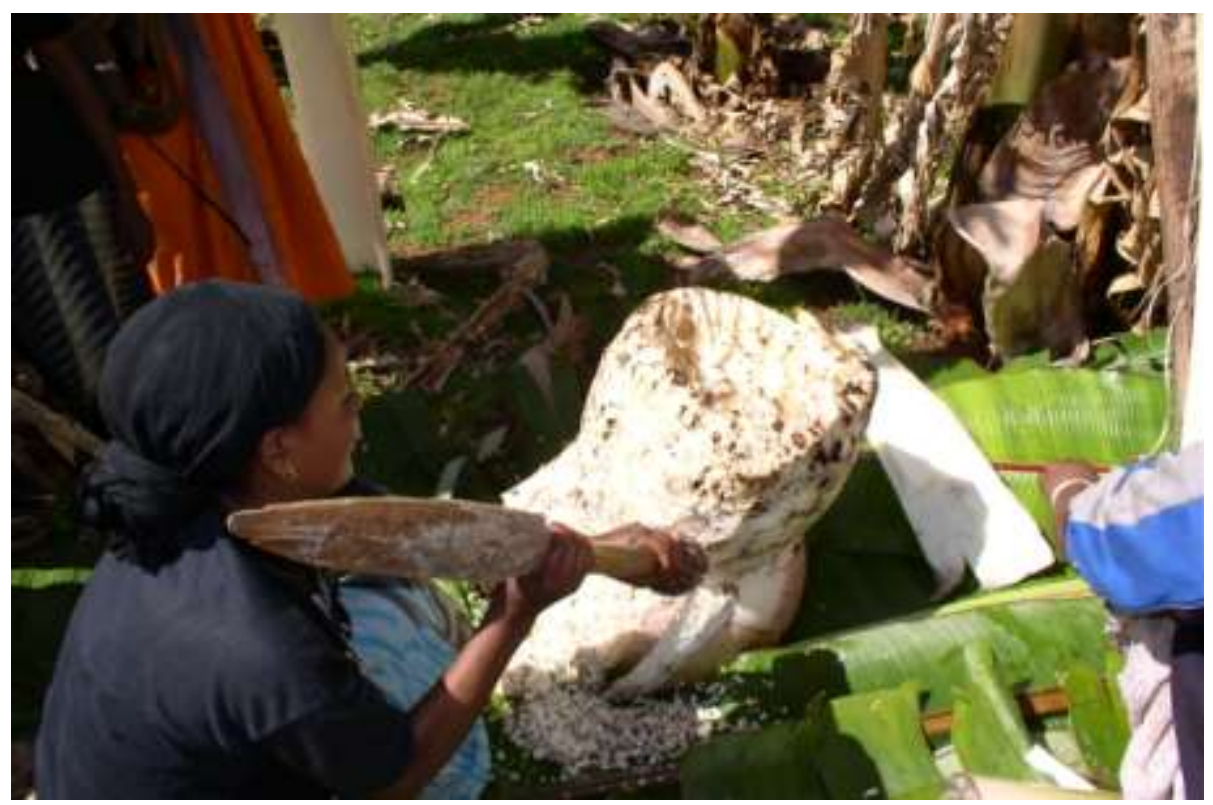

Zdjęcie 18 Rozdrabnianie guba za pomoca žəbanəgiba.

Inne kobiety zajmują się płatami guba. Układają je na specjalnych belkach zwanych wataro umieszczanych pod odpowiednim kątem. Kobiety siedząc przy belkach, nogą uniesioną wysoko, przytrzymuja płaty eset. Za pomocą specjalnego, bambusowego narzędzia - səbisa ${ }^{8}-$ ścierają płaty ruchem od góry (pod nogą) do dołu na drobne wióry i płyn atamät’o. Czynność tę wykonują do momentu, aż z obrabianej części płata zostaną same sznurki - kanča.

\footnotetext{
${ }^{7}$ Žabanəgiba - drewniane narzędzie wykonane z jednego kawałka, służące do rozdrabniania wähəta na wióry. Posiada długi, profilowany trzonek zapobiegający ślizganiu się rąk. Zakończony jest zębami po obwodzie oraz specjalnym wgłębieniem środku ułatwiającym skrobanie.

${ }^{8}$ Sabisa - specjalny, bambusowy kij służący do ścierania płatów guba na wióry
} 


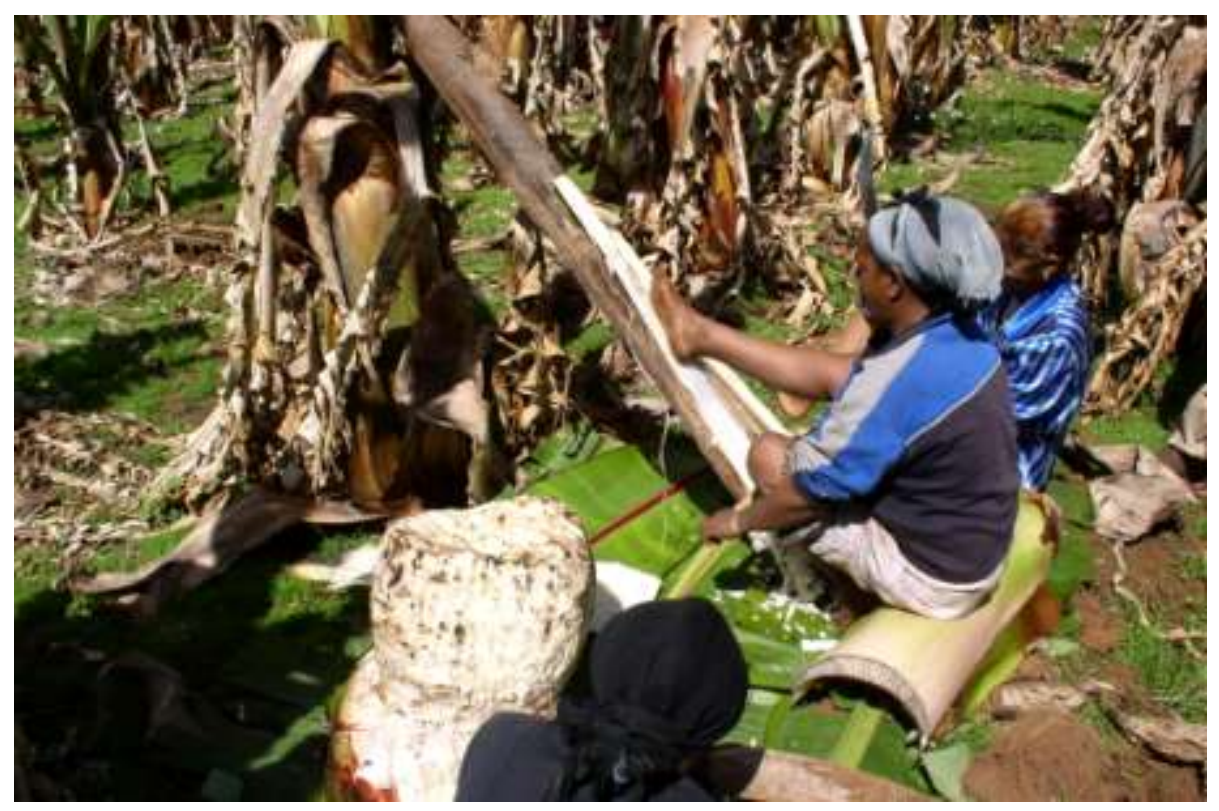

Zdjęcie 19. Ścieranie guba na belce watero.

Następnie płat odwraca się, powstałe sznurki obwiązuje się wokół stopy i dużego palca podniesionej nogi i powtarza się czynność ścierania.

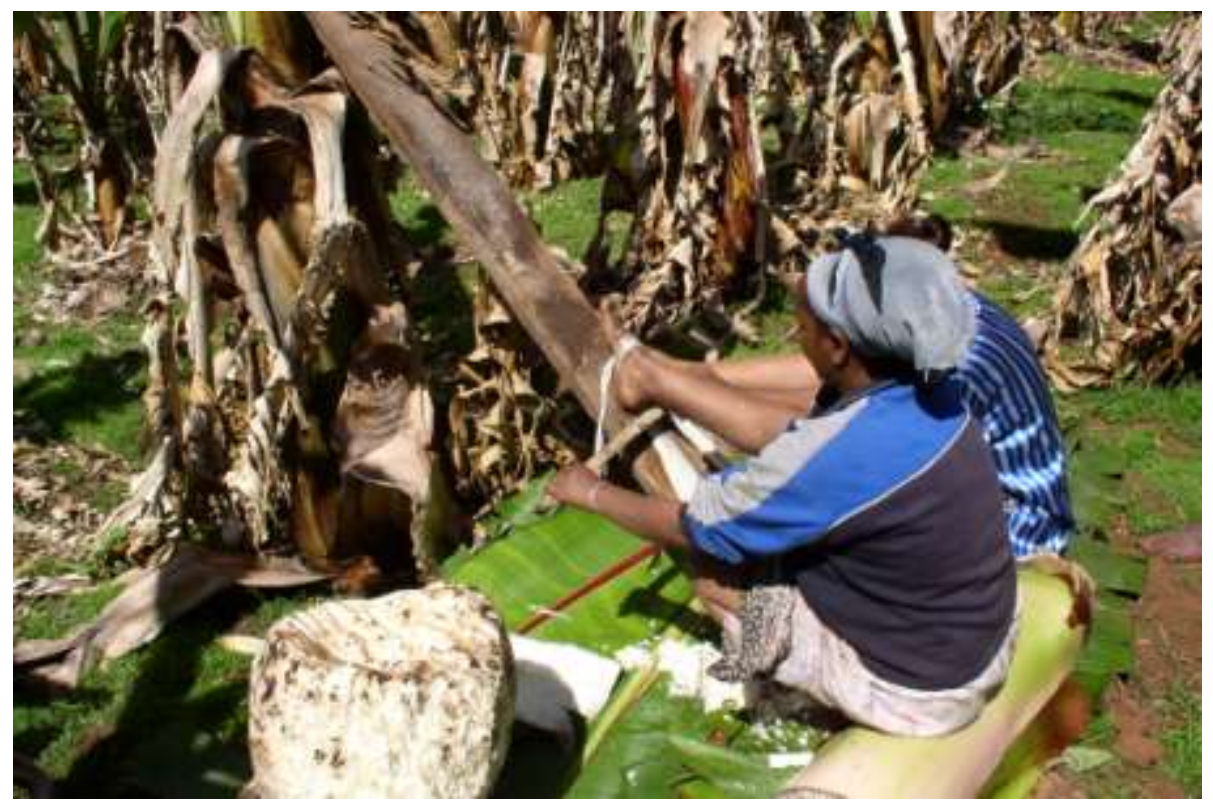

Zdjęcie 20. Drugi etap ścieranie guba. Stopa obwiazana sznurkami kanč.

Z wiórów wähəta i płatów guba powstaje mieszanka zwana kesra. Rozkłada się ją bardzo luźno na świeżych liściach eset, szczelnie przykrywa i obkłada kamieniami dla zabezpieczenia przed wiatrem. Proces fermentacji trwa $7 \mathrm{dni}$. Od tego momentu powstały produkt nazywa się wusa. Zbija się go w stertę i znów przykrywa szczelnie liśćmi, aby puścił sok. Proces ten trwa przeciętnie od 3 do 7 dni, ale o jego długości decyduje pani domu. Zakończenie tego procesu $\mathrm{w}$ odpowiednim momencie świadczy o tym, jak dobrą jest ona gospodynią.

Następnie w pobliżu domu wykopuje się płytką dziurę w ziemi. Wykłada się ją szczelnie suchymi częściami pnia, zwanymi änwa. Tak przygotowane miejsce nazywa się yewusa goğä. Przekłada się do niego wusa i szczelnie przykrywa änwa i obkłada kamieniami. Miejsce to służy 
jako magazyn. Wusa może być w nim przechowywane nawet kilka lat, pod warunkiem, że co kilka miesięcy wyciąga się je, przewietrza i zmienia änwa.

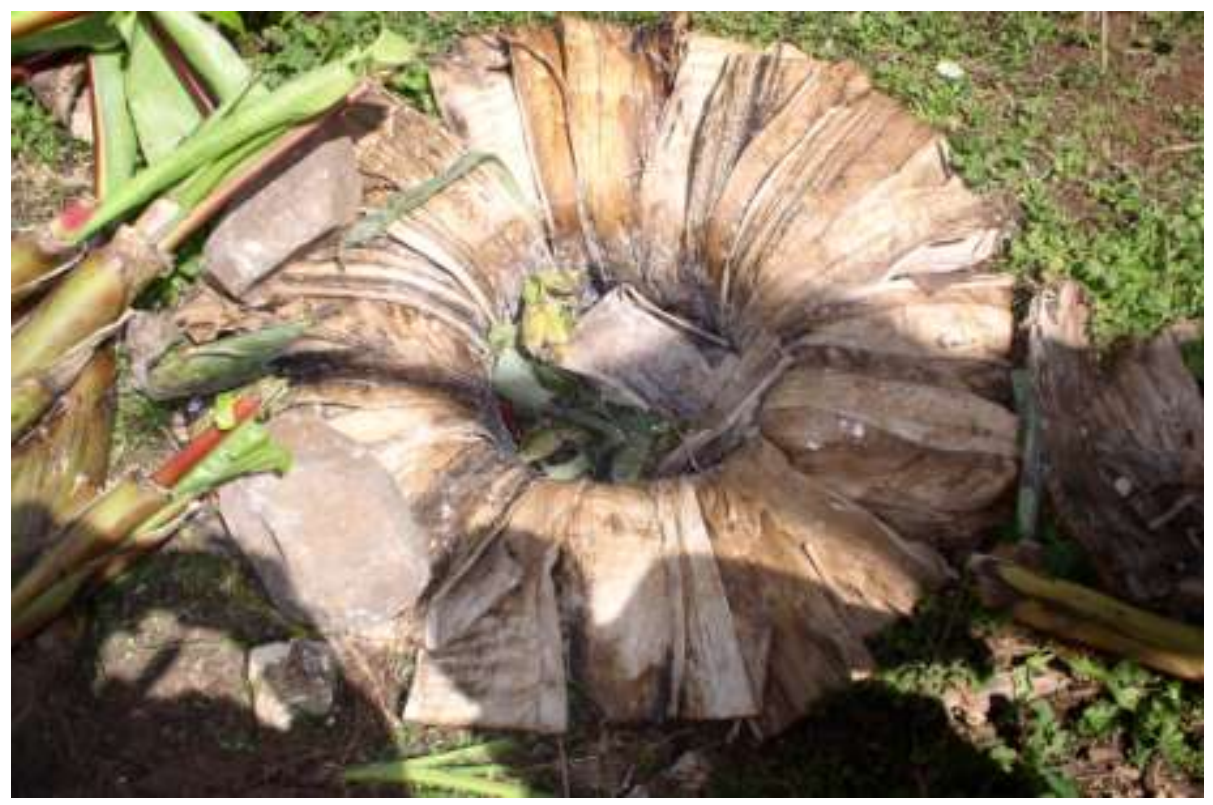

Zdjęcie 21. Yäwusa goğä.

Gospodyni pobiera odpowiednie porcje wusa na codziennie potrzeby. Za pomocą kanča (sznurków) splątanych w odpowiedni pęk, wykręca sok z masy. Potem na desce zwanej zämbor ̈̈9, starannie, nawet przez kilka godzin, kroi masę za pomocą bardzo ostrego, długiego i szerokiego noża zwanego yäsäməborä sända ${ }^{10}$ i drewnianej nakładki chroniącej rękę przed okaleczeniem.

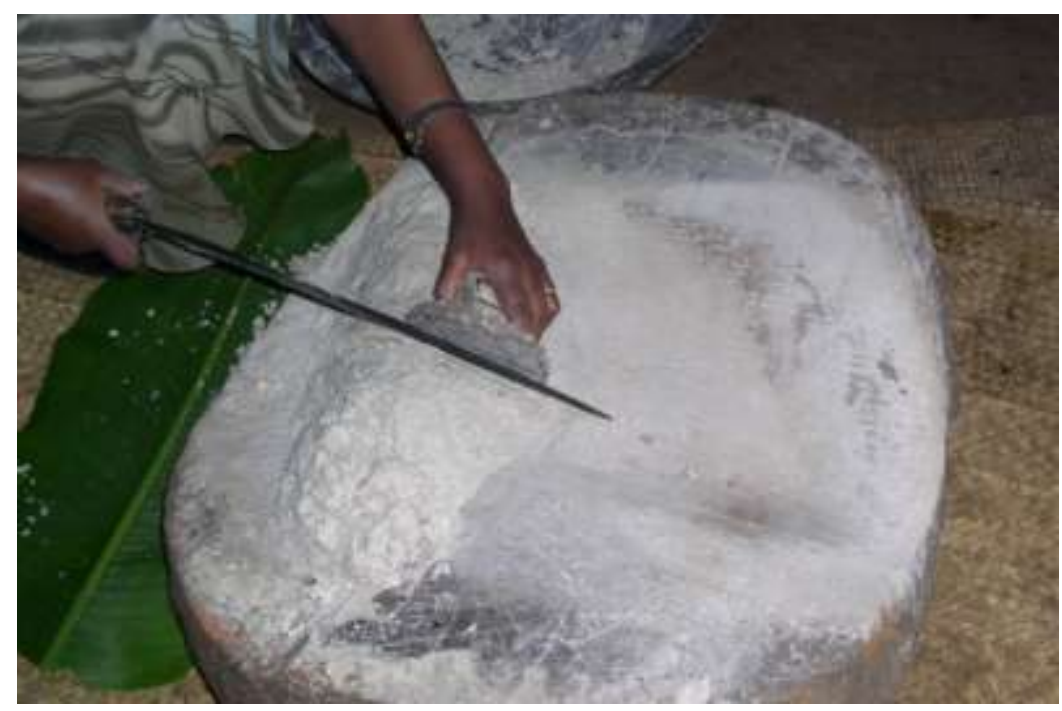

Zdjęcie 22. Krojenie surowego wusa.

\footnotetext{
${ }^{9}$ Zämborä-gruba (ok. 20cm) deska, na której kobiety kroją wusa. Wykonana jest z jednolitego kawałka twardego drewna, ma kształt okrągły lub owalny o średnicy ok. $1 \mathrm{~m}$.

${ }^{10}$ Yäsäməborä sända - długi (ok. $50 \mathrm{~cm}$ ), szeroki nóż o drewnianej profilowanym trzonku zabezpieczającym przed ślizganiem i skaleczeniem, służący do krojenia masy wusa. Stosuje się go razem z drewnianą nakładką z półokrągłym uchwytem chroniącym rękę podczas krojenia.
} 
Od niedawna niektóre kobiety stosują łatwiejszy sposób na wykonanie wusa, zwłaszcza, gdy potrzebne są jego duże ilości, np. w czasie wielkich uroczystości takich jak wesele czy pogrzeb. Aby uniknąc męczącego wyciskania i długotrwałego krojenia owijają masę w materiał, kładą na specjalne sitko zwane wänəfit i przyciskają kamieniem. W ten sposób wyciskają sok i uzyskują twardą masę. Następnie mieszają i wybierają twarde nitki łyka. Dzięki temu nie muszą tak dokładnie kroić wusa, a efekt jest podobny. Powstaje coś w rodzaju grubo zmielonej mąki. Miesza się ją z wodą i powstaje ciasto. Następnie formuje się placki o grubości ok. $1 \mathrm{~cm}$. Na suchej patelni zwanej mədad ${ }^{11}$ układa się liście eset, na nich placki i ponownie przykrywa się liśćmi, aby nie wyschły.

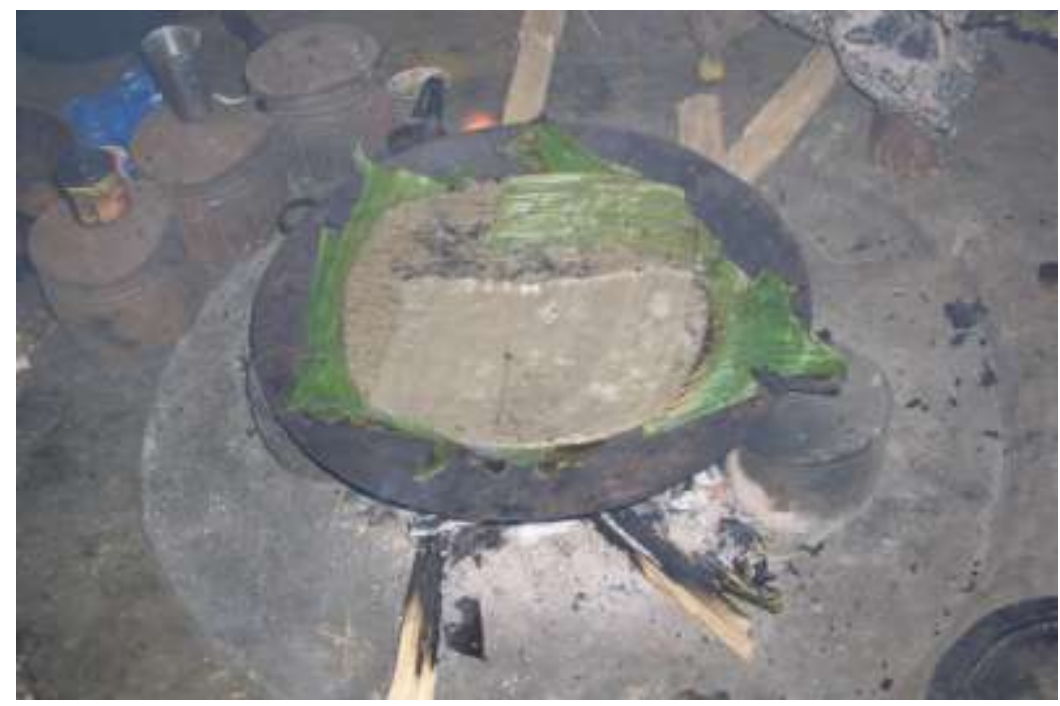

Zdjęcie 23. Smażenie wusa.

Smaży się je ok. 15-20 min., a następnie łamie lub kroi w prostokąty. Jeśli wówczas widać wyraźnie nitki łyka, bardzo źle to świadczy o gospodyni.

Wusa jada się codziennie podobnie jak chleb. Stanowi podstawę wyżywienia mieszkańców plemienia Gurage. Przygotowuje się je bez żadnych dodatków, dlatego po usmażeniu samo w sobie jest niesmaczne, jałowe, wilgotne i dość twarde. Spożywa się je popijając mlekiem, śmietana, je z białym serem lub ze specjalną kapustą tzw. yəguraga gomen.

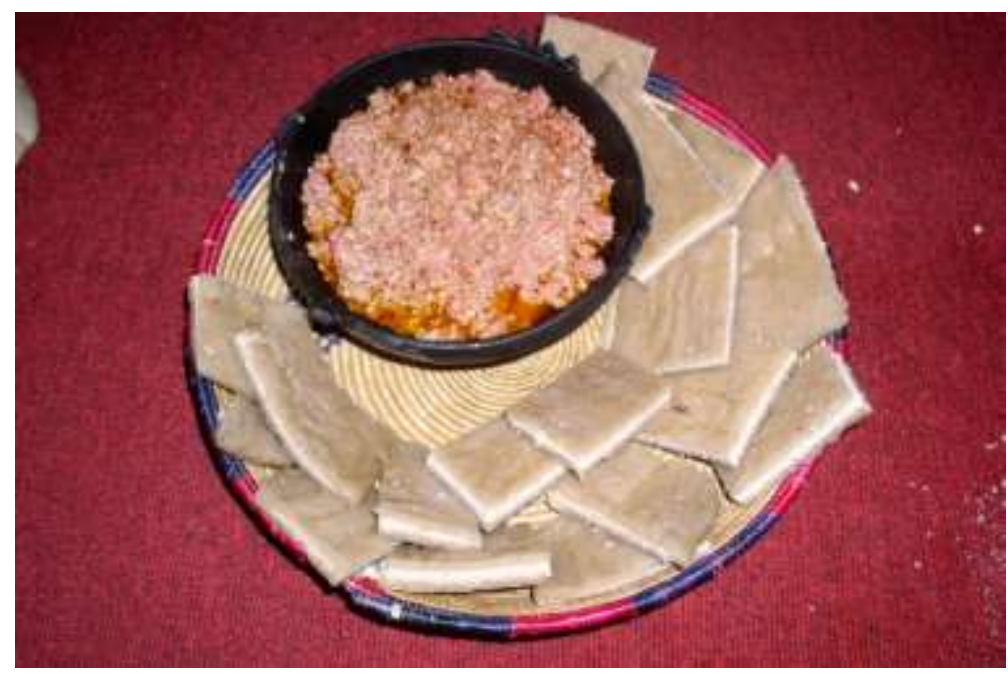

Zdjęcie 24. Przygotowane do spożycia wusa z lekko podsmażonym katfo.

${ }^{11}$ Madad-metalowa, płaska patelnia do smażenia wusa. 
Jednakże najlepiej smakuje w połączeniu z katfo czyli surową krojoną wołowiną z masłem klarowanym ze specjalnymi przyprawami. W takiej postaci jest najczęściej podawane w restauracjach.

\subsection{Atomät’o}

W procesie rozdrabniania wähəta i skrobania płatów guba na wusa powstaje mętny płyn. Spływa on na podstawione liście eset lub $\mathrm{w}$ odpowiednio przygotowane i zabezpieczone zagłębienie. Osadza się on w postaci śnieżnobiałej, twardej masy - atəmät’o. Kobieta odlewa sok. Suchą masę może zużyć od razu lub podobnie jak wusa przechowywać w odpowiednio przygotowanym dołku w ziemi nawet przez długi czas.

$\mathrm{Z}$ atวmät’’ przygotowuje się następujące potrawy:

> Yäatəmät’ gänfo - atəmät’o miesza się z zimną wodą. Powstaje bardzo rzadkie ciasto, które następnie wlewa się do garnka z wrzącą wodą. Gotuje się ok. 5 min intensywnie mieszając. Aby lepiej zobrazować ten proces można porównać go do przygotowania kisielu. Gotowe wykłada się na gliniany talerz zwany bitər, posypuje papryką i polewa masłem klarowanym $\mathrm{z}$ różnymi przyprawami. Potrawę tę zjada się za pomocą specjalnej długiej łyżki wykonanej z krowiego rogu zwanej anəkäfo. Podaje się na śniadanie, ale tylko szczególnym osobom, np. kobiecie po urodzeniu dziecka, młodej pani zaraz po ślubie, gościom, których chce się uhonorować. Podawane jest również osobie, która została wyleczona z tasiemca, aby nabrała sił.

$>$ Yäatวmät’ wusa - do atzmät’o dodaje się niewielką ilość wody i ugniata ciasto z odrobiną soli. Robi się z niego cienki placek i smaży na patelni ok. 20 min (proces podobny do robienia pizzy). Różni się od wusa tym, że smaży się go bezpośrednio na patelni, bez użycia liści eset. Powstaje suchy placek, który podaje się do kawy podobnie jak ciasto.

$>$ Yäatวmät’ fyrfyr - do atəmät’’ dodaje się odrobinę wody i kruszy się, a następnie smaży na patelni. Wykłada się na talerz i dokładnie miesza z papryką i masłem klarowanym. Podaje się go na różne okazje, najczęściej jako przekąskę do kawy.

\subsection{Wähəta}

Wähəta można przygotowywać w podobny sposób jak ziemniaki. Oczyszcza się go z ziemi, obiera i kroi na kawałki, a następnie gotuje w glinianym garnku na palenisku. Gdy kawalki zmiękną odcedza się wodę. Można je zjadać popijając kwaśną śmietaną, najlepiej jeśli pochodzi ona od krowy, która właśnie urodziła cielaka. Ma ona wtedy najcenniejsze właściwości.

W zależności od gatunku eset gotowana wähəta spożywana jest dla określonych celów medycznych. Do najszlachetniejszych gatunków eset o działaniu leczniczym należą:

$>$ Astara - stosowana na odbudowę uszkodzonej tkanki mięśniowej, zwłaszcza przy naderwaniach ścięgien i mięśni.

> Der - wykorzystywana przy złamaniach, wspomaga zrastanie się kości.

$>$ Guarəyä - stosowana na wrzody skórne, przyspiesza ich szybsze ropienie, podobnie jak w Polsce lek o nazwie ichtiol.

$>$ Kabəna - wykorzystywana w leczeniu chorób serca i krążenia.

$>$ Šäbrrat - podawana kobietom, które $\mathrm{w}$ czasie porodu mają problemy $\mathrm{z}$ wydalaniem $\mathrm{z}$ organizmu łożyska.

\subsection{Inne wykorzystanie eset}

Najczęściej wykorzystywanymi częściami eset do wyrobu artykułów gospodarstwa domowego są sznurki kanča oraz wysuszone i pozbawione liści łodygi čambina, zwykle cięte w dhugie, cienkie pasy.

Wyrabia się z nich między innymi:

$>$ Gämäd - grube sznury, liny wykonane z kanča, służące, np. do wiązania bydła. 


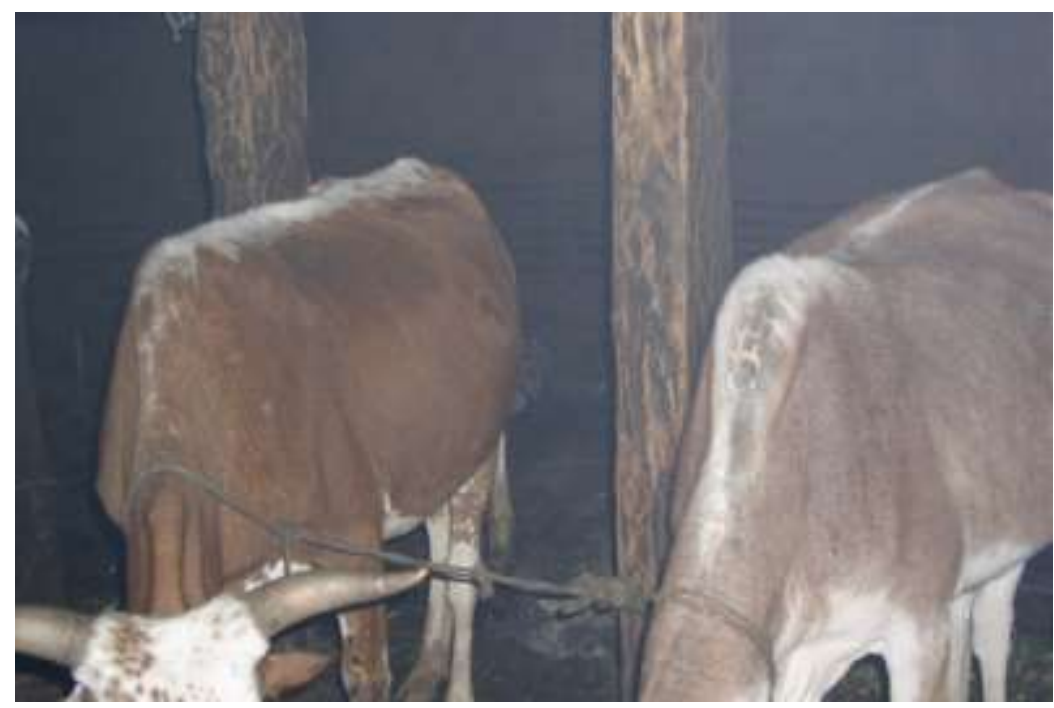

Zdjęcie 25. Bydto powiqzane za pomocq gämädə.

Kabuwat - gruby, sprężysty materac do spania, zrobiony ze suchych łodyg i kanča. Świeżo po ścięciu łodygi są mocno nasączone wodą i twarde, po wysuszeniu robią się sprężyste jak gąbka. Przeplata się je sznurkami kanča warstwa po warstwie. Z czasem tracą one swoją sprężystość i kabuwat robi się niewygodny więc wymienia się go na nowy.

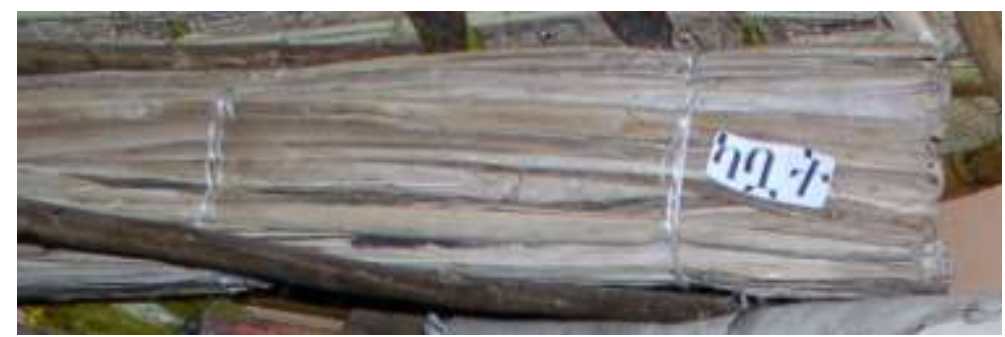

Zdjęcie 26. Kabuwat.

> Ğabä - z suchych, pociętych na pasy łodyg i kanča wyplata się dywaniki i maty do spania. Różnią się między sobą jakością w zależności od ilości kanča i czasem potrzebnym do ich wykonania.

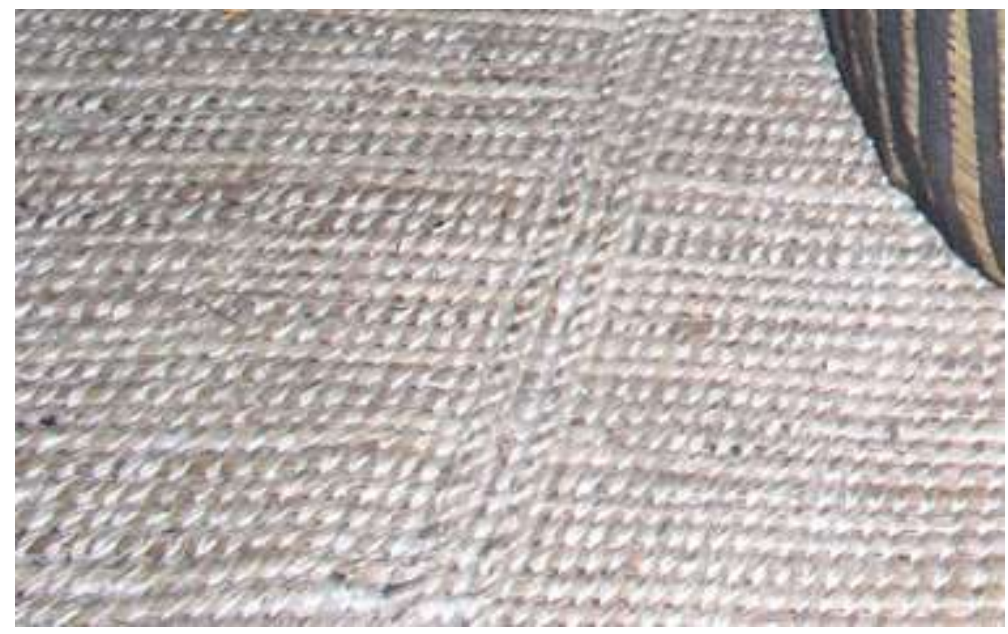

Zdjęcie 27. Ğəbä. 
Yəwädärä - maty do jedzenia:

$>$ Codziennego użytku, mieszanka kanča i čəmbina.

> Najwyższej jakości, wykonane z samego kanča. Mogą być w różnokolorowe pasy. Są bardzo drogie i nie wszystkich na nie stać. Rozkładane są tylko w czasie ważnych uroczystości lub gdy w sposób szczególny chce się uhonorować gościa.

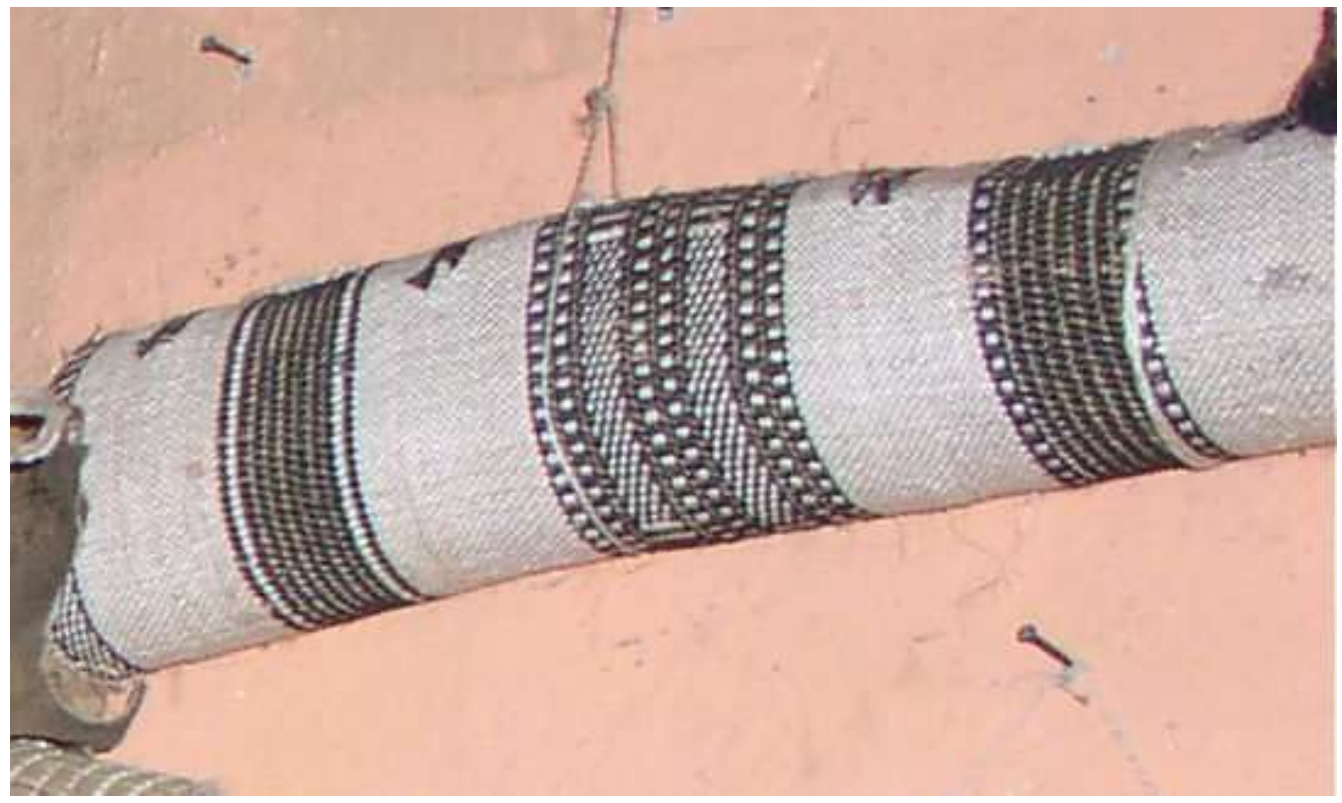

\section{Zdjęcie 28. Yəwädärä.}

Čefat - okragłe obręcze stanowiące podstawki do naczyń.

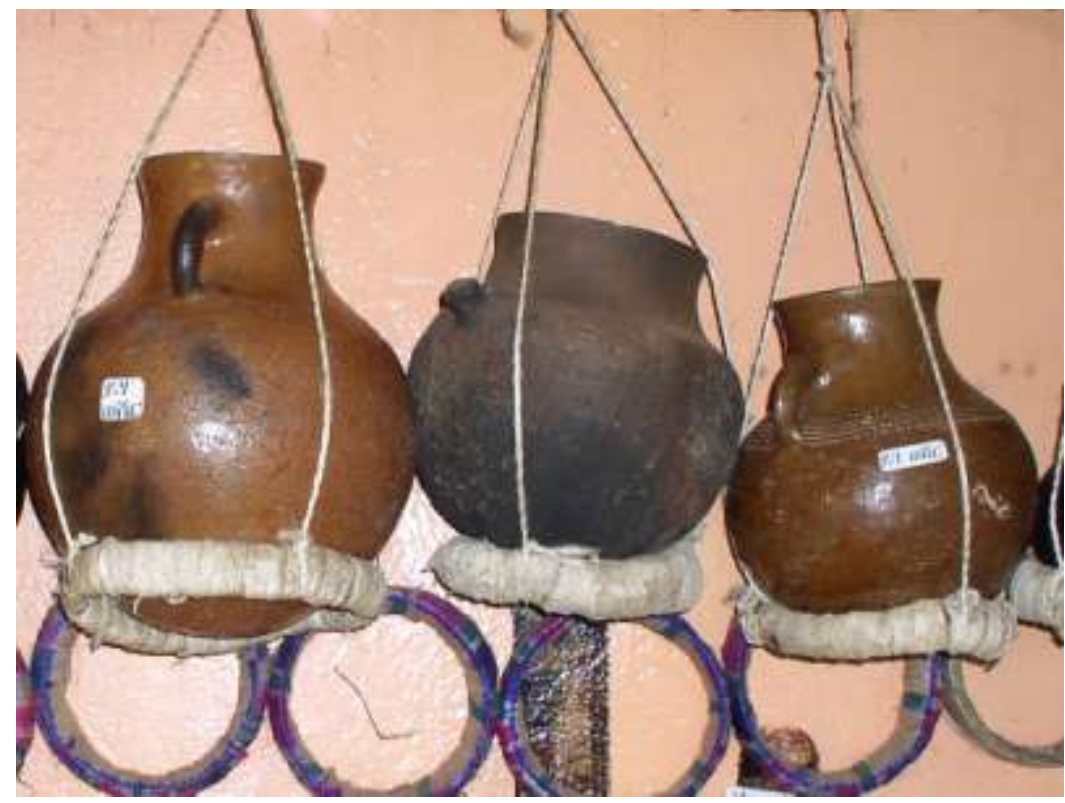

Zdjęcie 29. Čefat - podstawki do naczyń wraz z wieszakami z kanča.

Tərasə - poduszka do spania. Można ją wykonać między innymi z änwa.

> Təläsa - miseczka dopasowana do dłoni powstała z kawałka świeżego liścia eset podgrzanego lekko na palenisku, nie bezpośrednio na ogniu. Pod wpływem ciepła nabiera on właściwości plastycznych. Składa się go w stożek i odcina, tak że powstaje kółko. 
Następnie robi się zakładkę, aby powstała miseczka. Z pomocą anəkäfo nakłada się do niej katfo (tatar wołowy).

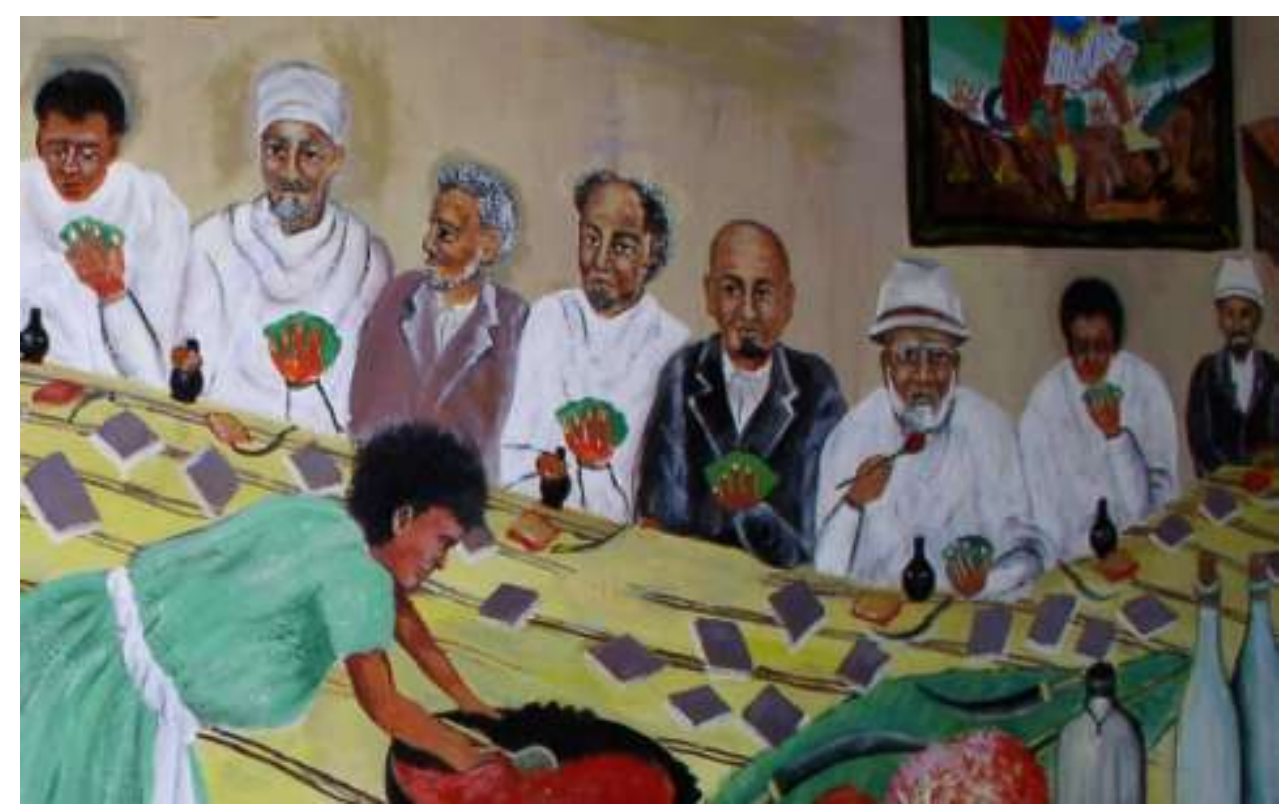

Zdjęcie 30. Mężczyźni jędzq̨y katfo w taläsa.

$>$ Jest w zwyczaju, aby osobie zmarłej w czasie przygotowań do pogrzebu podłożyć pod głowę kawałek čambina.

Eset stanowi także doskonałą karmę dla zwierząt. Praktycznie całą roślinę można zużyć. Jednak jest na tyle cenna, że podaje się ją jedynie w porze suchej, gdy brakuje innego pokarmu. Liście i łodygi kroi się za pomocą noża muria ${ }^{12}$

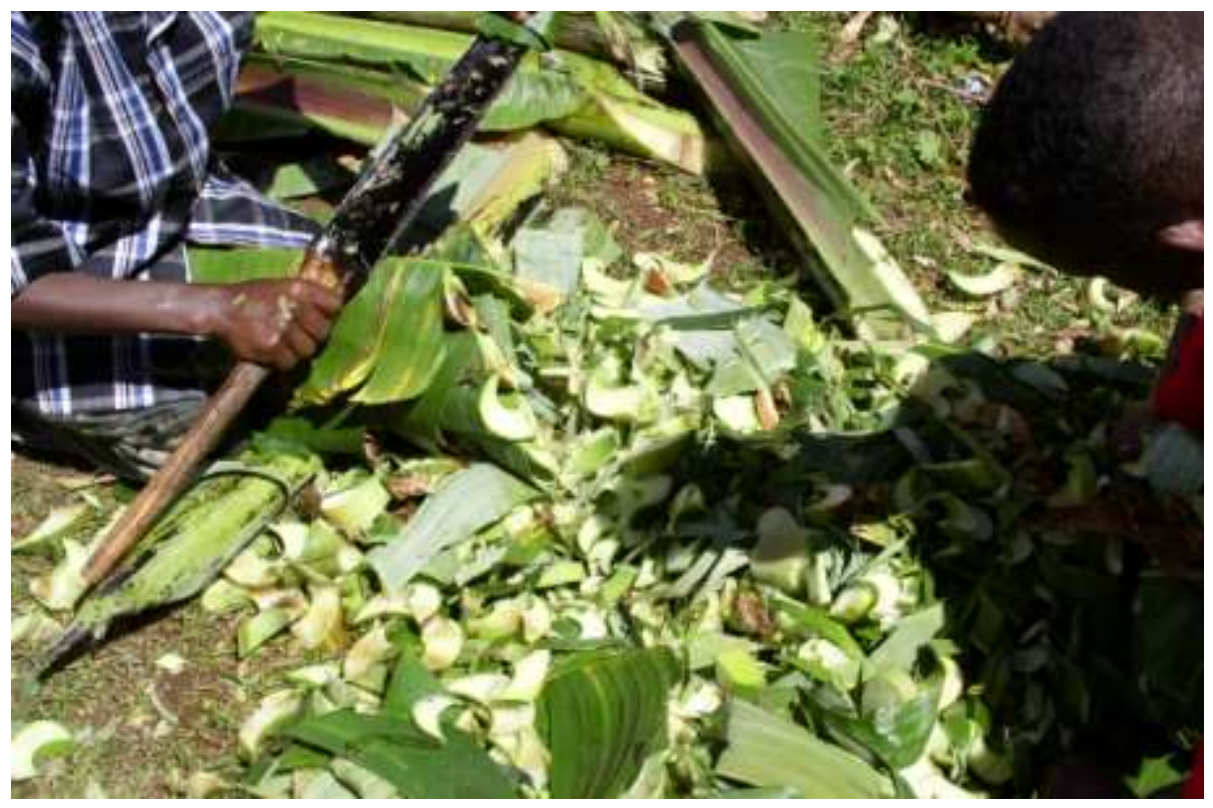

Zdjęcie 31. Przygotowanie katäla i čambina na pokarm dla bydta.

${ }^{12}$ Muria - długi, bardzo ostry nóż używany do krojenia liści i łodyg eset. 
Kokosa - suche, obumarłe liście, które w razie potrzeby stosuje się jako opał. Wykorzystuje się je tylko w wyjątkowych sytuacjach, ponieważ szybko się palą i wydzielają duże ilości dymu.

\section{Zakończenie}

Uprawa eset jest bardzo żmudna i długotrwała. Wiele lat również trwa proces tworzenia odpowiedniej gleby pod uprawę. Muszą być też zachowane pewne zasady, aby plony się udały. Najlepiej jak tradycja uprawy eset przekazywana jest z pokolenia na pokolenie, prowadzona jest $\mathrm{w}$ sposób nieprzerwany i co bardzo ważne w tym samym miejscu. Choć uprawa tej rośliny jest tak bardzo wymagająca, jest ona opłacalna, ponieważ rekompensuje to swoim wszechstronnym zastosowaniem. Kto uprawia eset rzadko bywa głodny. 
Seifu Gebru: Eset - wielofunkcyjna roślina Etiopii i terminologia zwiqzana z niq.

\section{Bibliografia}

Almagehu, N. 1992. Eset. Addis Adeba: Bole Painting Enterprise.

Alemu, D. 1994. Gogot. Wenkitie.

Gabreyesus, H. 1991. The Gurague and Their Culture. New York: Los Angeles: Vantage Press.

Gizaw, K. 1998. Yägurage yäməgəbə asärar. Addis Abeba.

Shack, W.A. 1969. The Gurage. A People of the Ensete Culture. London: New York: Nairobi: Oxford University Press. 